\title{
Application of Biochar for Soil Remediation
}

\author{
Tom Sizmur,* Richard Quilliam, Aline Peregrina Puga, \\ Eduardo Moreno-Jiménez, Luke Beesley, and Jose L. Gomez-Eyles
}

\begin{abstract}
Research into the use of biochar for the remediation of contaminated soils has expanded rapidly over the past 5 yr. We review recent developments in the field and present the findings emanating from small-scale batch sorption experiments, through soil incubations and bioassays, to large-scale field experiments. We discuss the evidence that these experiments have contributed toward a mechanistic understanding of how biochar is capable of remediating soils contaminated with both organic and inorganic contaminants. The effects of biochar pyrolysis temperature, biochar source material, soil type, and contaminant type on the performance of biochars for remediation are identified. The risks associated with applying biochar to uncontaminated agricultural soils are discussed. Knowledge gaps and questions are identified which, if addressed, will considerably advance the application of biochar as a soil remediation tool in the future.
\end{abstract}

\begin{abstract}
Abbreviations: AC, activated carbon; DOC, dissolved organic carbon; EDTA, ethylenediaminetetraacetic acid; EVA, ethyl vinyl acetate; HOC, hydrophobic organic contaminant; $\mathrm{PAH}$, polycyclic aromatic hydrocarbons; TECAM, triolein-embedded cellulose acetate membranes.

T. Sizmur, Soil Research Centre, Dep. of Geography and Environmental Science, School of Archaeology, Geography and Environmental Science, Univ. of Reading, UK; R. Quilliam, Biological \& Environmental Sciences, Univ. of Stirling, Stirling, FK9 4LA, UK (richard.quilliam@stir.ac.uk); A.P. Puga, Instituto Agronômico de Campinas, Avenida Barão de Itapura, 1481, CEP 13012-970, Campinas (SP), 13020-902, Brazil (linepuga@gmail.com); E. Moreno-Jiménez, Universidad Autónoma de Madrid, 28049 Madrid, Spain (eduardo.moreno@uam.es); L. Beesley, The James Hutton Institute, Craigiebuckler, Aberdeen, AB15 8QH, UK (luke.beesley@hutton.ac.uk); and J.L. Gomez-Eyles, Integral Consulting Inc., 719 2nd Ave., Suite 700, Seattle, WA 98104 (jgeyles@integral-corp.com). *Corresponding author (t.sizmur@reading.ac.uk)..
\end{abstract}

doi:10.2136/sssaspecpub63.2014.0075

Agricultural and Environmental Applications of Biochar: Advances and Barriers. SSSA Special Publication 63. M. Guo, Z. He, and M. Uchimiya, editors.

(c) 2015. SSSA, 5585 Guilford Rd., Madison, WI 53711, USA. 
Biochars possess a number of remarkable properties that make them suitable for the remediation of contaminated soils, including a high internal surface area, negative charge, and resistance to degradation. Generally, the higher the temperature that organic material is pyrolyzed, the higher the surface area of the resulting biochar (Gomez-Eyles et al., 2013a), although there is evidence that some biochar pores collapse and decrease surface area at very high pyrolysis temperatures (Lua and Guo, 1998). There is a considerable negative charge over the surface of biochar (Mukherjee et al., 2011), which attracts positively charged metals and organic compounds to the internal biochar surface from the soil solution. In doing so, the concentration of metals and organic contaminants in the soil solution can be reduced (Beesley et al., 2010), along with their current availability for uptake by organisms (i.e., their bioavailability [Semple et al., 2004]), or their potential to become available for uptake by organisms (i.e., their bioaccessibility [Semple et al., 2004; Gomez-Eyles et al., 2011; Houben et al., 2013a]).

The surface of biochars produced during pyrolysis at lower temperatures $\left(200-400^{\circ} \mathrm{C}\right)$ are rich in "oxygen-containing functional groups" that enable the creation of surface complexes between cations (e.g., $\mathrm{Cu}^{2+}, \mathrm{Ni}^{2+}, \mathrm{Cd}^{2+}, \mathrm{Pb}^{2+}$, and $\mathrm{Zn}^{2+}$ ) and the biochar surface (Beesley and Marmiroli, 2011; Uchimiya et al., 2011a). This negative charge can also increase soil $\mathrm{pH}$ after biochar application to contaminated soils because the negative surface attracts hydrogen ions from the soil solution. A higher soil $\mathrm{pH}$ serves to further increase the sorption of metals from solution because of the deprotonation of $\mathrm{pH}$-dependent cation exchange sites on soil surfaces (Rees et al., 2014b), especially in acidic soils.

Some biochars contain a considerable mineral ash component (e.g., up to $50 \%$ for manure manure-derived, or even $85 \%$ for bone meal-derived source materials [Amonette and Joseph, 2009]). Minerals such as carbonates, phosphates, and sulfates can cause some toxic elements (e.g., $\mathrm{Pb}$ ) to precipitate out of solution. Because the precipitates are rather insoluble (especially $\mathrm{Pb}$ salts, and especially at high $\mathrm{pH}$ ), this mechanism can contribute considerably to the remediative capacity of biochars (Cao et al., 2009).

Finally, biochar degrades very slowly with predicted $C$ half-lives ranging from $10^{2}$ to $10^{7} \mathrm{yr}$ (Zimmerman, 2010). Therefore, during the timescales that most soil remediation projects operate ( 10 to $100 \mathrm{yr})$, biochar can be considered an inert material. An advantage of this recalcitrance is the potential to sequester soil contaminants for a long period of time. However, oxygen-containing functional groups on the surface of the biochar may release cations into solution over time as they are replaced with hydrogen ions (Kim et al., 2013).

\section{Why Biochar Is a Suitable Soil Amendment for Remediation of Contaminated Soil}

The objective of contaminated land remediation projects is to reduce the risk of harm that contaminants could cause to organisms. This is achieved by breaking or reducing source-pathway-receptor linkages (Bardos et al., 2002) (Fig. 1). A source is the physical location of a contaminant itself, or the location from which it is being emitted. A receptor is the location where it can cause harm (e.g., human tissue, other organisms, or water bodies). The pathway is the mechanism by which the contaminant moves from the source to the receptor. When a contaminant can move from a source to a receptor in sufficient doses to cause harm, then the contaminant 


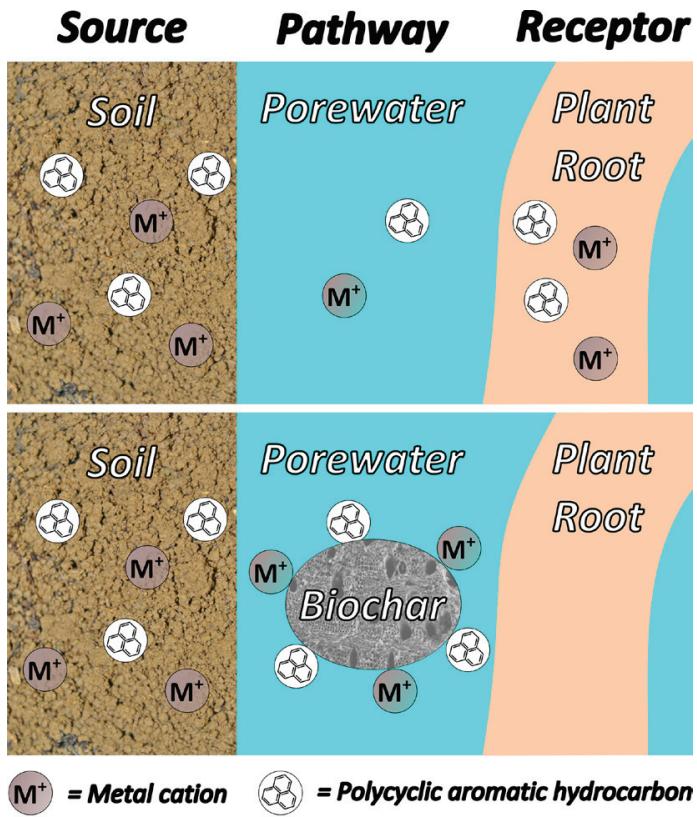

Fig. 1. Diagram to demonstrate the remediation of organic and inorganic contaminants in soil by biochar, breaking a sourcepathway-receptor linkage.

is considered a pollutant and the soil is considered polluted soil. In many cases the simplest (and most cost effective) method to remediate polluted soil is to remove the source of a contaminant (e.g., excavate it and deposit it elsewhere), or to remove the receptor (e.g., put a fence around the site to restrict access). However, these propositions are often impractical and expensive when widespread soil contamination occurs or when a contaminated site is in active use.

There are many pathways by which contaminants in soils may migrate from sources to receptors but most require the dissolution of a contaminant into the soil solution. Biochar breaks source-pathway-linkages by adsorbing contaminants on its surface and thereby reducing the concentration of contaminants in the soil solution (Beesley and Marmiroli, 2011). Remediation is achieved if biochar irreversibly adsorbs contaminants that come into the soil solution, eliminating the pathway to receptors (Fig. 1). After sorption on the surface of the biochar, contaminants can be considered unavailable to organisms and no longer pose a risk of causing harm.

\section{Comparison of Biochar and Activated Carbon}

Like biochar, activated carbon (AC) is produced by pyrolysis, usually of coal, but also waste biomass products like coconut shells. However, an extra activation step is involved in its manufacture usually using steam (Rittenhouse et al., 2014) but also chemicals (e.g., phosphoric acid (Lim et al., 2010), chitosan (Zhou et al., 2013), potassium hydroxide (Regmi et al., 2012), or hydrogen peroxide (Xue et al., 2012)). This activation further develops the inner pore structure of the carbons giving it a superior surface area (generally $>900 \mathrm{~m}^{2} / \mathrm{g} \mathrm{N} \mathrm{N}_{2} \mathrm{BET}$ ) relative to biochar (generally $1-350 \mathrm{~m}^{2} / \mathrm{g} \mathrm{N}_{2} \mathrm{BET}$ ). This makes $\mathrm{AC}$ more favorable for the remediation of 
hydrophobic organic contaminants (HOCs) because HOCs generally have greater affinity for higher surface area carbons (Cao et al., 2011; Gomez-Eyles et al., 2013a; Rittenhouse et al., 2014). The use of AC to break pollutant pathways has provided a new direction in the remediation of contaminated sediments, especially those impacted with HOCs (Ghosh et al., 2011), and is currently being deployed by the sediment remediation industry after successful reductions of HOC bioavailability in field pilots (Beckingham and Ghosh, 2011; Cho et al., 2012).

Given the superior surface area and sorption capacity of ACs relative to biochars, ACs have been recommended as the most appropriate carbon amendment for the remediation of HOC-impacted sediments (Gomez-Eyles et al., 2013b). However, when produced in bulk, biochar is cheaper than AC $(<\mathrm{USD} \$ 1000$ per ton vs. USD $\$ 2500$ per ton) and is often produced from waste resources. Furthermore, biochar can be less detrimental to soil biota health than AC (Hale et al., 2013), and can be more effective at stimulating plant growth than AC because of enhancements in soil quality (Denyes et al., 2013). Biochar is also generally less dense than $\mathrm{AC}$, which could favor the kinetics of contaminant mass transfer from the soil to the carbon as there are a higher number of particles per unit mass relative to $\mathrm{AC}$ if they are amended at the same dose and particle size. However, ACs will still possess a higher number of sorption sites for HOCs per unit mass and are therefore likely to be more effective at reducing HOC bioavailability in most soils. Most comparative studies between the two have shown superior performance of the AC for HOCs (Cao et al., 2009; Cao et al., 2011; Gomez-Eyles et al., 2013b; Hale et al., 2012; Rittenhouse et al., 2014). However, in a recent field pilot their performance was not statistically different (Denyes et al., 2013). On the other hand, most comparative studies between the two for inorganic contaminants showed superior performance by the biochar relative to the AC (Cao et al., 2009, 2011), although this was not the case for mercury (Gomez-Eyles et al., 2013b). Optimum amendment choice will therefore depend of the contaminants of concern and may vary between different soils. Treatability studies using site-specific soils could be performed to aid amendment selection.

\section{The Research Scientist's Toolbox}

As research scientists developing techniques for the remediation of contaminated soils with biochar, we have a number of tools and techniques available to us. Research on the remediation of contaminated soils with biochar can take place at a variety of scales. These range from highly controlled microcosm environments in the laboratory to field experiments conducted under prevailing ambient conditions. Environmental research usually evolves from the laboratory to the field, often alongside a reduction in the number of treatments tested. In this chapter we will highlight recent literature and discuss the contribution that each of the following experimental approaches (summarized in Table 1) have made to our understanding of the science behind the application of biochar for soil remediation.

- Batch sorption studies

- Biochar-soil incubations

- Bioassays

- $\quad$ Field experiments 


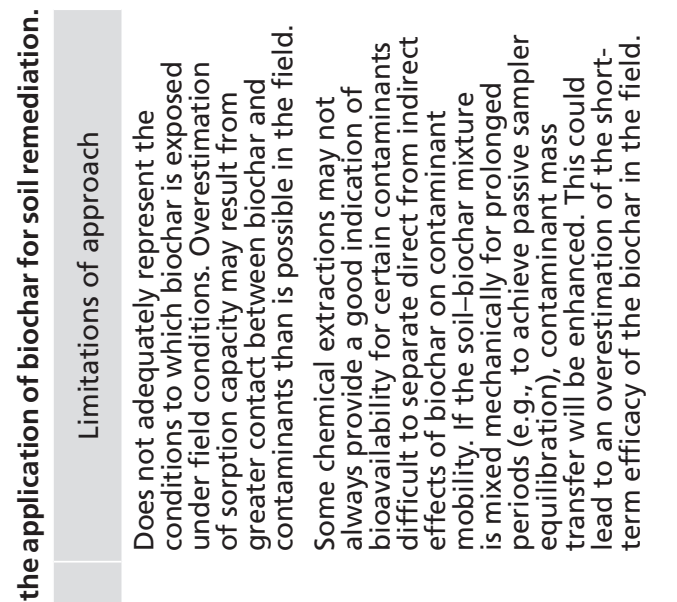

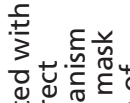

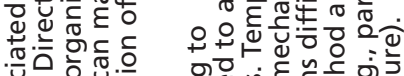

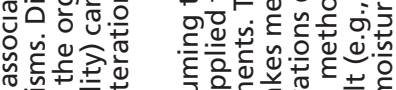

खे

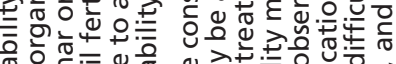

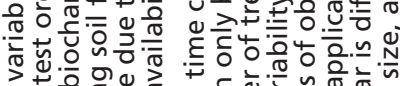

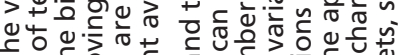

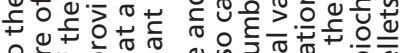
$\circ$ 는

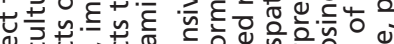

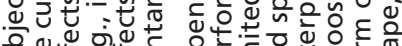

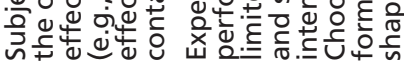

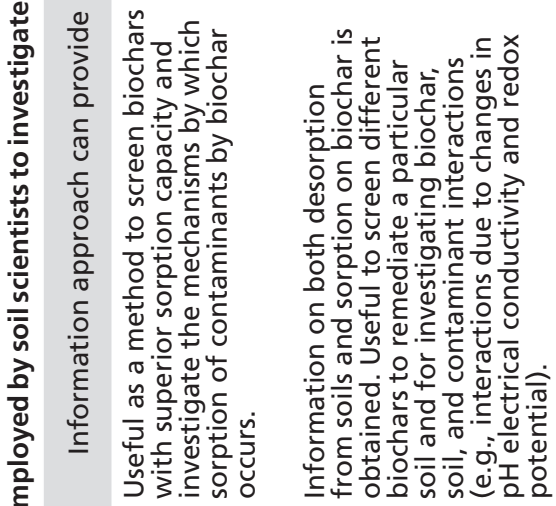

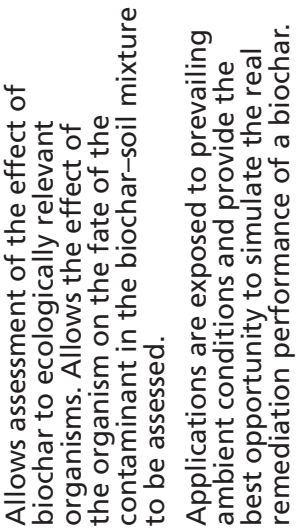

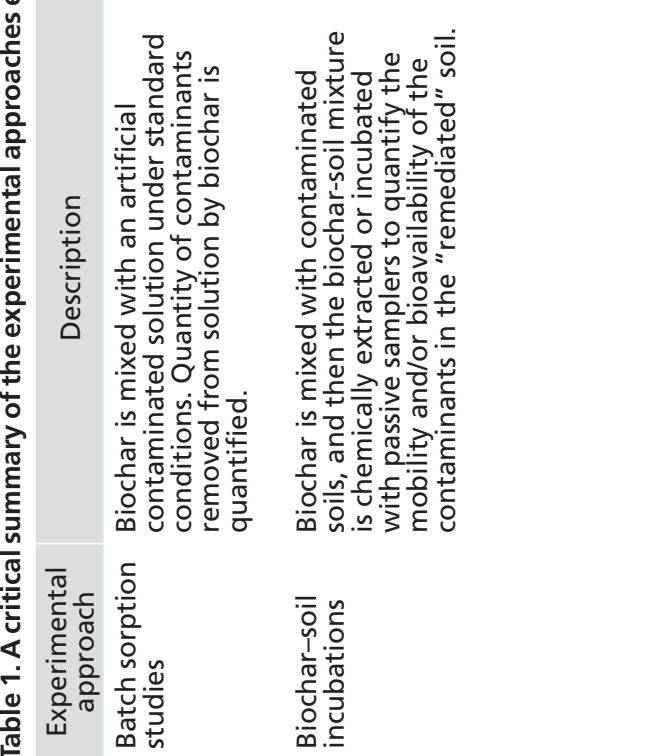

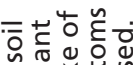
施苍

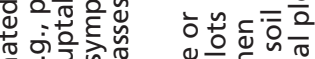

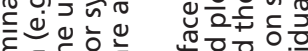
है

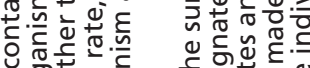

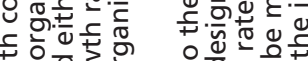

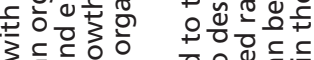
उٓ

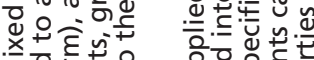

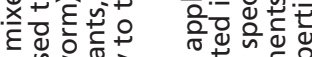

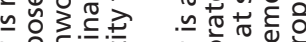

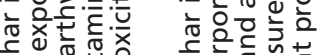

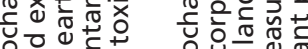

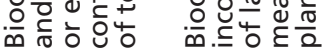

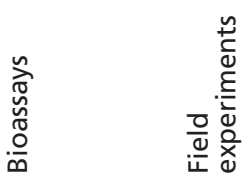




\section{Batch Sorption Studies}

Batch sorption experiments enable researchers to quantify the capacity of a biochar to adsorb contaminants from a solution. Biochar is mixed with a solution containing a known concentration of a contaminant for a known time period under controlled temperature conditions. For metals and readily soluble organic contaminants the solution can be separated from the biochar (usually by centrifugation and/or filtration). The concentration of contaminant remaining in solution is then measured. For HOCs, detection can be more challenging because of the extremely low concentrations of these chemicals in the freely dissolved phase. Instead, equilibrium passive sampling methods are employed. Plastic polymers submerged in the solution accumulate HOCs and can be used to infer freely dissolved concentrations (Ghosh et al., 2014). The difference between the concentration at the start and the end of the incubation is used to infer the quantity of contaminant adsorbed to the surface of the biochar. The concentration of pollutants that are adsorbed is calculated by subtracting the end concentration from the concentration at the start.

\section{Sorption Isotherms}

By determining the quantity of contaminant adsorbed to the biochar surface at constant temperature and a range of contaminant concentrations, an adsorption isotherm can be generated. The adsorption isotherm can then be fitted to a model. The two most common models for fitting sorption isotherms on biochars are the Freundlich and Langmuir models (Fig. 2). The Langmuir model assumes that the adsorbate forms a monolayer over a homogenous surface (Sparks, 2003). The model assumes that there is a maximum number of identical sites where sorption can occur. Therefore, the maximum adsorption capacity of a given biochar can be derived by fitting the model to experimental data. Comparing the adsorption capacities of different biochars allows researchers to predict their relative performance at reducing the bioavailability of contaminants in soils. For example, Chen et al. (2011) showed that the maximum $\mathrm{Cu}$ and $\mathrm{Zn}$ sorption capacities of a $450^{\circ} \mathrm{C}$ pyrolyzed corn straw-derived biochar was double that of a hardwood-derived biochar pyrolyzed at $600^{\circ} \mathrm{C}$. Gomez-Eyles et al. (2013b) also conducted a series of sorption isotherms to evaluate biochar sorption capacity of HOCs, mercury, and methylmercury relative to ACs. The Langmuir model has recently been fitted to batch sorption data for several biochar source materials, but mostly inorganic contaminants and often in combination with the Freundlich model (Table 2).

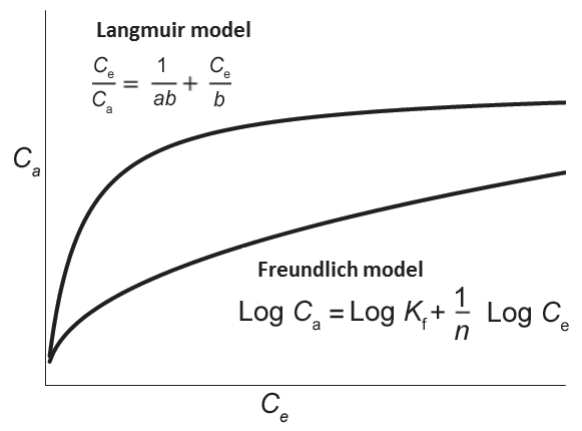

Fig. 2. Idealized Langmuir and Freundlich models for the adsorption of contaminants on the surface of biochar. $C_{a}$ is the concentration of contaminant adsorbed on the biochar, $C_{e}$ is the equilibrium concentration of contaminant in solution, $\boldsymbol{b}$ is the Langmuir maximum adsorption capacity, $K_{f}$ represents the Freundlich relative sorption capacity, $n$ and a are adsorption constants for the Freundlich and Langmuir models, respectively. 
Table 2. A summary of recent publications that fit batch sorption data to Langmuir and/ or Freundlich models. $t$

\begin{tabular}{|c|c|c|c|c|}
\hline $\begin{array}{l}\text { Biochar source } \\
\text { material }\end{array}$ & Contaminant(s) & Model(s) fitted & $R^{2}$ & Reference \\
\hline $\begin{array}{l}\text { Meat and bone } \\
\text { meal }\end{array}$ & $\mathrm{Zn}$ & Langmuir & 0.825 & $\begin{array}{l}\text { Betts et al. } \\
\text { (2013) }\end{array}$ \\
\hline Swine manure & $\mathrm{Cr}(\mathrm{III})$ & $\begin{array}{l}\text { Langmuir and } \\
\text { Freundlich }\end{array}$ & $\begin{array}{l}0.641-0.999 \\
0.636-0.996\end{array}$ & $\begin{array}{l}\text { Wnetrzak et al. } \\
\text { (2014) }\end{array}$ \\
\hline Almond shell & $\mathrm{Ni}$ and $\mathrm{Co}$ & $\begin{array}{l}\text { Langmuir and } \\
\text { Freundlich }\end{array}$ & $\begin{array}{l}0.989-1.000 \\
0.896-0.995\end{array}$ & $\begin{array}{l}\text { Kılıç et al. } \\
(2013)\end{array}$ \\
\hline $\begin{array}{l}\text { Rice husk and } \\
\text { dairy manure }\end{array}$ & $\begin{array}{l}\mathrm{Pb}, \mathrm{Cu}, \mathrm{Zn} \text {, and } \\
\mathrm{Cd}\end{array}$ & $\begin{array}{l}\text { Langmuir and } \\
\text { Freundlich }\end{array}$ & $\begin{array}{l}\text { Rice husk: } \\
0.96-0.99 \\
\text { Dairy manure: } \\
0.74-0.98 \\
\text { Rice husk: } \\
0.82-0.89 \\
\text { Dairy manure: } \\
0.86-0.97\end{array}$ & Xu et al. (2013) \\
\hline $\begin{array}{l}\text { Swine and } \\
\text { dairy manure }\end{array}$ & $\begin{array}{l}\mathrm{Cu}, \mathrm{Zn}, \mathrm{Cd} \text { and } \\
\mathrm{Pb}\end{array}$ & $\begin{array}{l}\text { Langmuir and } \\
\text { Freundlich }\end{array}$ & $\begin{array}{l}\text { Swine manure: } \\
0.979-0.999 \\
\text { Dairy manure: } \\
0.969-0.999 \\
\text { Swine manure: } \\
0.821-0.997 \\
\text { Dairy manure: } \\
0.765-0.994\end{array}$ & $\begin{array}{l}\text { Kołodyńska et } \\
\text { al. (2012) }\end{array}$ \\
\hline Sawdust & Methyl blue & $\begin{array}{l}\text { Langmuir and } \\
\text { Freundlich }\end{array}$ & $\begin{array}{l}0.994 \\
0.865\end{array}$ & $\begin{array}{l}\text { Wang et al. } \\
(2013)\end{array}$ \\
\hline $\begin{array}{l}\text { Municipal } \\
\text { waste }\end{array}$ & $\mathrm{As}(\mathrm{V})$ & $\begin{array}{l}\text { Langmuir and } \\
\text { Freundlich }\end{array}$ & $\begin{array}{l}0.961-0.992 \\
0.859-0.995\end{array}$ & Jin et al. (2014) \\
\hline Crop residues & $\mathrm{Cd}$ & Freundlich & $0.939-0.964$ & $\begin{array}{l}\text { Sun et al. } \\
(2014)\end{array}$ \\
\hline $\begin{array}{l}\text { Tree bark and } \\
\text { vine shoot }\end{array}$ & $\begin{array}{l}\mathrm{Cd}, \mathrm{Cu}, \mathrm{Ni}, \mathrm{Pb}, \\
\text { and } \mathrm{Zn}\end{array}$ & Freundlich & $\begin{array}{l}\text { Tree bark: } \\
0.94-0.99 \\
\text { Vine shoot: } \\
0.98-0.99\end{array}$ & $\begin{array}{l}\text { Venegas et al. } \\
(2015)\end{array}$ \\
\hline Wheat straw & $\begin{array}{l}\text { Hexachloroben- } \\
\text { zene }\end{array}$ & Freundlich & 0.93 & $\begin{array}{l}\text { Song et al. } \\
(2012)\end{array}$ \\
\hline $\begin{array}{l}\text { Cottonseed } \\
\text { Hull }\end{array}$ & $\begin{array}{l}\text { Deisopropylat- } \\
\text { razine }\end{array}$ & Freundlich & $0.99-0.84$ & $\begin{array}{l}\text { Uchimiya et al. } \\
\text { (2012) }\end{array}$ \\
\hline Beech wood & $\begin{array}{l}\text { Imazamox, } \\
\text { methyl- } \\
\text { desphenyl- } \\
\text { chloridazon, } \\
\text { metazachlor } \\
\text { oxalic acid, and } \\
\text { metazachlor } \\
\text { sulfonic acid }\end{array}$ & Freundlich & $>0.95$ & $\begin{array}{l}\text { Dechene et al. } \\
\text { (2014) }\end{array}$ \\
\hline Maple wood & $\begin{array}{l}\text { Napthalene, } \\
\text { Benzene and } \\
\text { 1,4-dinitroben- } \\
\text { zene }\end{array}$ & Freundlich & $0.85-0.99$ & $\begin{array}{l}\text { Lattao et al. } \\
(2014)\end{array}$ \\
\hline $\begin{array}{l}\text { Pine wood, } \\
\text { peanut hull, } \\
\text { hardwood, acai } \\
\text { pit, poultry } \\
\text { litter, and } \\
\text { phragmites }\end{array}$ & $\begin{array}{l}\text { PCBs, PAHs, and } \\
\text { DDTs }\end{array}$ & Freundlich & $0.50-1.0$ & $\begin{array}{l}\text { Gomez-Eyles et } \\
\text { al. (2013) }\end{array}$ \\
\hline
\end{tabular}


The Freundlich model is an empirical equation that has the advantage of allowing different sorption sites to have different adsorption energies (Sparks, 2003). The sites with the highest adsorption energy "fill up" first. This allows the model to be applied to adsorption on heterogeneous surfaces. The Freundlich model has been recently used to model the sorption of a large range of organic and inorganic contaminants to biochars produced from several different source materials (Table 2). However, the Freundlich equation does not allow the calculation of a maximum adsorption capacity. Several recent papers publish the constants associated with both the Langmuir and Freundlich models fitted to experimental data on the sorption of contaminants to biochar (Table 2).

\section{Batch Sorption Studies to Elucidate Biochar Sorption Mechanisms}

Batch sorption studies can also be very useful to improve our mechanistic understanding of how contaminants sorb to biochar. Better understanding these mechanisms is important as biochar production parameters (e.g., source material, final pyrolysis temperature, heating rate, and duration or surrounding gases) can be manipulated to produce biochars with optimum characteristics (e.g., surface area, pore size distribution, and surface chemistry) for the sorption of a contaminant of concern (Lattao et al., 2014; Sun et al., 2012a; Uchimiya et al., 2011b).

The maximum metal sorption capacity of a biochar generally increases with pyrolysis temperature to a peak around $350-400^{\circ} \mathrm{C}$, after which sorption decreases with pyrolysis temperature (Kołodyńska et al., 2012; Uchimiya et al., 2011b; Zhang et al., 2013a). This peak is concurrent with a peak in the cation exchange capacity of biochar found in the same temperature range (Gomez-Eyles et al., 2013a). Several studies report contrasting mechanisms of metal sorption between high and low pyrolysis temperature biochars (Dong et al., 2013; Gomez-Eyles et al., 2013a; Harvey et al., 2011; Uchimiya et al., 2010). Metal sorption on low-temperature biochars primarily occurs because of ion exchange with oxygen-containing functional groups such as hydroxyls, carboxyls, and phenols (Dong et al., 2013). After high-temperature pyrolysis, the $\mathrm{C} / \mathrm{O}$ ratio of the biochar increases (Uchimiya et al., 2011b) and the surface becomes more electronegative (Fig. 3). Consequently, metal sorption primarily occurs because of an electrostatic interaction between the positively charged metal ions and negative charge associated with delocalised $\pi$-electrons on aromatic structures (Harvey et al., 2011). The chemisorption of metals by inner sphere complex formation is generally much stronger than the physisorption of metals via cation $-\pi$ interactions.

In general, biochars with higher surface areas have an enhanced ability to sorb HOCs, and increasing pyrolysis temperatures can enhance biochar surface area (Gomez-Eyles et al., 2013a) (Fig. 3), although there is some evidence that biochar pores collapse and decrease surface area at very high pyrolysis temperatures (Lua and Guo, 1998). For example, by keeping all other production parameters constant, Chen et al. (2008) clearly demonstrate how increasing pyrolysis temperature increased BET- $\mathrm{N}_{2}$ surface area, and this in turn favored the sorption of naphthalene and nitrobenzenes. However, BET-N $\mathrm{N}_{2}$ surface area on its own cannot fully predict HOC sorption to carbons (Bucheli and Gustafsson, 2000; Chun et al., 2004; Wang and Xing, 2007). Pignatello et al. (2006) point out how $\mathrm{N}_{2}$ sorption isotherms performed at $77 \mathrm{~K}$ can provide a good measure of biochar mesoporosity, but fail to quantify microporosity as $\mathrm{N}_{2}$ diffusion into micropores is severely limited at these temperatures. Instead, the authors couple the use of 


\section{Low temperature pyrolysis}

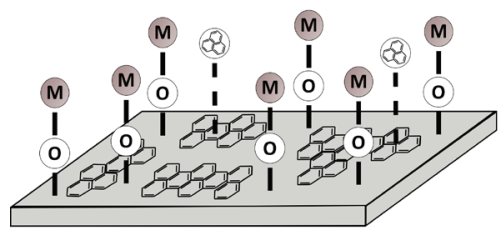

$$
\begin{aligned}
& \text { M } \\
& \text { I } \\
& \text { I } \\
& \text { I } \\
& \text { I } \\
& \text { I } \\
& \text { I }
\end{aligned}
$$

High temperature pyrolysis

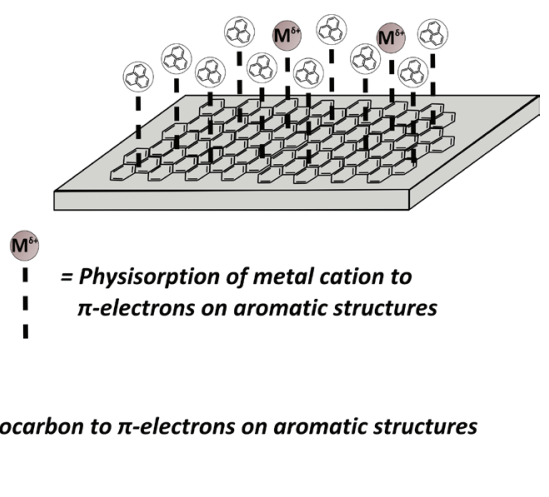

Fig. 3. Conceptual diagram depicting the mechanisms of organic and inorganic contaminant sorption to high-temperature and low-temperature biochar. After lowtemperature pyrolysis $\left(300-500^{\circ} \mathrm{C}\right)$ a high density of oxygenated functional groups provides cation exchange sites for optimal metal sorption. After high-temperature pyrolysis $\left(>500^{\circ} \mathrm{C}\right)$ the biochar increases in aromaticity and there is greater sorption of organic compounds by cation $-\pi$ interactions.

$77 \mathrm{~K} \mathrm{~N}_{2}$ isotherms with $\mathrm{CO}_{2}$ sorption isotherms conducted at $273 \mathrm{~K}$ to get an accurate measurement of both meso- and microporosity. Lattao et al. (2014) used measures of both of these parameters and others likely to affect HOC sorption to biochar in a comprehensive study to better understand the factors controlling sorption. All these parameters on their own failed to predict sorption, although a model relating sorption to a weighted sum of micro- and mesoporosity was more successful. Hydrophobic organic contaminant sorption therefore depends on a complex interrelationship between the contaminant properties (e.g., hydrophobicity, polarity, and steric size and/or shape) and the biochar properties. Further studies are needed to better understand these relationships so biochar production from remediation purposes can be optimized.

\section{Summary}

Batch sorption experiments and the fitting of adsorption isotherm models (e.g., the Langmuir and Freundlich models) have enabled researchers to observe the effects of biochar production parameters (e.g., pyrolysis temperature and source material) on the sorption capacity of the resulting biochar. Furthermore, combination with complimentary biochar characterization (e.g., C/O ratio and surface area) has improved our understanding of the mechanisms of sorption.

\section{Biochar-Soil Incubations}

Laboratory incubations of biochar-soil mixtures enable us to test the performance of a biochar as a soil amendment to reduce contaminant mobility. Incubations offer advantages over batch sorption studies because they capture both the (i) desorption of contaminants from the soil surface and (ii) adsorption of contaminants on the surface of the biochar. Batch sorption experiments only assess the latter. 
Therefore, soil-biochar incubations are likely to provide more robust predictions of biochar remediation performance in the field, if they are performed using field contaminated soils. Like batch sorption studies, conditions (e.g., temperature and moisture) are often well controlled to ensure reproducibility. Typically, biochar is mixed with a contaminated soil and incubated at a given moisture content for a known period of time. The mobility of the contaminant in the soil-biochar mix is then determined by extracting a known quantity of the soil with an aqueous solution or mild solvent (e.g., $\mathrm{CaCl}_{2}$, chelating agents, butanol, methanol, or acids) or an infinite hydrophobic sink (e.g., cyclodextrin or Tenax) to predict the contaminant fraction that can become available for uptake or degradation (Reichenberg and Mayer, 2006). The concentration of contaminant present in the extraction solution can then be determined analytically. There is consensus in more recent work that measuring freely dissolved concentrations of organic and inorganic contaminants with passive samplers (e.g., solid-phase micro extraction [Jonker et al., 2007], polyethylene [Adams et al., 2007], POM [polyoxymethylene] [Jonker and Koelmans, 2001], ethyl vinyl acetate [EVA] [Andrade et al., 2014], trioleinembedded cellulose acetate membranes [TECAM] [Tao et al., 2009], or diffusive gradients in thin films [Zhang et al., 2001]) can provide the best indication of the actual bioavailability of contaminants in soils (Gomez-Eyles et al., 2012; Nolan et al., 2005). These methods enable an assessment of the efficacy of a particular biochar by its ability to reduce the mobility or availability of contaminants in contaminated soils.

\section{Chemical Methods to Assess Contaminant Mobility and Availability in Soil-Biochar Mixtures}

Column-leaching experiments have been widely adopted to determine the effect of biochar on the mobility of contaminants in soils. Experiments can involve the one-time introduction of water to the top of a column containing a soil-biochar mix or the circulation of water through a column until equilibrium is reached. Beesley and Marmiroli (2011) constructed flow-through columns to determine the capability of biochar to immobilize $\mathrm{Cd}$ and $\mathrm{Zn}$. Although considerable dissolved carbon was leached from the soil-biochar mix, $\mathrm{Cd}$ and $\mathrm{Zn}$ were immobilized and the immobilization could not be reversed by leaching with water at $\mathrm{pH}$ 5.5. The leachability of pentachlorophenol from soil was assessed in a columnleaching experiment and was reduced by $43 \%$ after amendment with bamboo biochar (Xu et al., 2012). Cabrera et al. (2011) showed that biochars with higher surface areas decreased the leaching of the herbicides fluometuron and 4-chloro2-methylphenoxyacetic acid in an agricultural soil.

Soil porewater can be extracted from soils with Rhizon soil moisture samplers which mimic the uptake of water by plant roots. The concentration of contaminants in the extracted porewater can be determined analytically. Rhizon samplers enable repeated extraction of porewater from pots, columns, or soil pits with minimal disturbance of the soil profile. They consist of a porous plastic material connected to a tube to which a vacuum can be applied to draw water out of the soil. The samplers can be inserted horizontally into pots or columns through predrilled holes and remain in place for the duration of an experiment, enabling repeat sampling (Karami et al., 2011; Sizmur et al., 2011c). Beesley et al. (2010) showed that biochar consistently reduced $\mathrm{Cd}$ concentrations 10 -fold in porewater samples extracted from a multi-element polluted soil with Rhizon samplers. 
Park et al. (2011) used Rhizon samplers to repeatedly collect porewater from pots amended with chicken manure and green waste-derived biochars. The biochars reduced $\mathrm{Cd}$ and $\mathrm{Pb}$ porewater concentrations but increased $\mathrm{Cu}$ concentrations. In contrast, Karami et al. (2011) showed that biochar reduced porewater $\mathrm{Cu}$ concentrations when sampled every $4 \mathrm{wk}$ with Rhizon samplers inserted in pots.

Equilibrium passive samplers can be used to infer the freely dissolved concentration of HOCs in the soil porewater which ultimately determines its equilibrium partitioning concentration in soil organisms (Gomez-Eyles et al., 2012; Reichenberg and Mayer, 2006). Polyoxymethylene and EVA have been used to evaluate biochar effectiveness at reducing polycyclic aromatic hydrocarbons (PAHs) and organochlorine bioavailability. No significant reduction in PAH concentrations in porewater were found by Brennan et al. (2014b), and only slight reductions in some DDT (dichlorodiphenyltrichloroethane) metabolites were reported by Andrade et al. (2014). However, Wang et al. (2013) measured reduced bioavailability of PCBs (polychlorinated biphenyls) using TECAM, and these reductions correlated strongly with reductions in uptake by plant roots.

Chemical extractions are often used to determine the bioavailability of contaminants in soils or soil-biochar mixtures (Gomez-Eyles et al., 2010; Rittenhouse et al., 2014; Xu et al., 2012). These extractions have the disadvantage that the amount of contaminant extracted is dependent on the strength of the solvent selected, and not only on the bioavailability of the contaminant. Extractions involve agitating a sample in a known volume of extractant solution for a known period of time, then centrifuging and/or filtering to separate the solid and solution phases. The concentration of metals in the solution is then determined analytically. Farrell et al. (2013) compared five different chemical extractions (water, $0.01 \mathrm{M} \mathrm{CaCl}_{2}, 0.05 \mathrm{M}$ ethylenediaminetetraacetic acid [EDTA], $0.5 \mathrm{M}$ acetic acid, and $1 \mathrm{M} \mathrm{NH}_{4} \mathrm{NO}_{3}$ ) to determine which was the most suitable for predicting plant uptake. None of the extractions were deemed suitable for multi-element polluted soils but EDTA, acetic acid, and water extractions were each significantly correlated with three metals (EDTA and acetic acid were correlated with Mo, As, and Cd, while water was correlated with $\mathrm{Mo}, \mathrm{As}$, and $\mathrm{Pb}$ ). Water extractions were also used by GomezEyles et al. (2011) to reveal a reduction in Cu mobility due to biochar amendment concurrently with a reduction in $\mathrm{Cu}$ uptake by earthworms. Large reductions in water extractable $\mathrm{Cu}, \mathrm{Pb}$, and $\mathrm{Zn}$ were also found after biochar addition to a mine soil (Sizmur et al., 2011e). Xu et al. (2012) reported 56 and 65\% reduction in distilled water and methanol extractable pentachlorophenol after biochar amendment. A popular choice of extracting solution is $0.01 \mathrm{M} \mathrm{CaCl}_{2}$ because it has a similar ionic strength as soil porewater (Houba et al., 2000). Calcium chloride has been used to show that biochar reduces extractable $\mathrm{Co}, \mathrm{Cu}$, and $\mathrm{Ni}$ in a depleted mine soil (Rodríguez-Vila et al., 2014), reduces $\mathrm{Cd}, \mathrm{Zn}$, and Pb bioavailability in a smelter-impacted soil (Houben et al., 2013b), and reduces Cd availability in contaminated rice paddies (Cui et al., 2011) and wheat fields (Cui et al., 2012). Cao et al. (2011) found amending a soil with a dairy-manure-derived biochar reduced $0.01 \mathrm{M} \mathrm{CaCl}_{2}$ extractable atrazine by 66 to $81 \%$. EDTA is a chelating agent capable of binding considerable concentrations of metals in solution. An EDTA extraction was used to demonstrate that a sewage sludge biochar reduced the bioavailability of $\mathrm{As}, \mathrm{Cr}, \mathrm{Co}, \mathrm{Ni}$, and $\mathrm{Pb}$ (but not $\mathrm{Cd}, \mathrm{Cu}$, and $\mathrm{Zn}$ ) in a contaminated rice paddy soil (Khan et al., 2013). Ethylenediaminetetraacetic acid extractable soil Cd was 
also reduced after addition of oil mallee biochar and wheat chaff biochar in $\mathrm{Cd}$ contaminated soil (Zhang et al., 2013b).

Depletive sampling techniques provide an infinite hydrophobic sink that remove all organic contaminants that readily enter the soil solution, and can therefore give a measure of the "rapidly desorbing fraction." This contaminant fraction is regarded as bioaccessible (currently bioavailable + potentially bioavailable [Semple et al., 2004]), and has been shown to provide a good measure of the total amount of HOCs readily available for degradation (Cornelissen et al., 1998; Reid et al., 2000). Reductions in PAH and hexachlorobenzene bioaccessibility after biochar amendment have been measured using cyclodextrin extractions and correlate well with reductions in uptake by earthworms (Gomez-Eyles et al., 2011; Song et al., 2012). Wang et al. (2013) also reported correlations in reduced PCB bioaccessibility measured using cyclodextrin and reduced PCB bioaccumulation in plant root tissues.

\section{Biochar-Soil-Contaminant Interactions}

Biochar-soil incubations allow researchers to account for any interactions between the soil components (e.g., organic matter and minerals), the biochar, and the contaminant which are not captured in clean isotherm studies. These interactions include the fouling, for example, pore blocking and/or scavenging, of the biochar surface by organic matter that reduces their efficacy to sorb HOCs (Pignatello et al., 2006), and subsequent reductions in dissolved organic matter concentrations that are known to play a major role on the complexation of heavy metals in solution (Gomez-Eyles et al., 2011; Weng et al., 2002).

Biochar increases the $\mathrm{pH}$ of a contaminated soil if the $\mathrm{pH}$ of the biochar is greater than the $\mathrm{pH}$ of the soil it is added to (Beesley et al., 2010; Sizmur et al., 2011e). This is due to the creation of metal oxides from base cations (e.g., K, $\mathrm{Ca}, \mathrm{Si}$, and $\mathrm{Mg}$ ) during pyrolysis (Novak et al., 2009). Therefore, biochar source materials with the greatest mineral concentrations result in the highest biochar ash components and have the highest $\mathrm{pH}$ (Lehmann et al., 2011). It is therefore intuitive that they will produce the greatest increase in soil $\mathrm{pH}$ following application. By increasing the soil $\mathrm{pH}$, the solubility of metal cations in the soil solution decreases. As a result, metals can precipitate out of solution, particularly as phosphates (Uchimiya et al., 2010). Biochars produced from manure source materials have particularly high mineral ash contents and can immobilize considerable concentrations of metals by this mechanism (Cao and Harris, 2010, Uchimiya et al., 2010). However, high phosphate concentrations in biochar may also result in mobilization of arsenate (Beesley et al., 2014).

For a biochar to be effective in reducing contaminant bioavailability in an amended soil, it has to improve its sorptive properties. Elevating the soil $\mathrm{pH}$ can increase the number of $\mathrm{pH}$-dependent cation exchange sites on the soil surface. Therefore, biochar removes metals from the soil solution not only by adsorbing metals on its own surface, but also by increasing the metals adsorbed by the soil itself. Houben et al. (2013b) demonstrated that the immobilization of Cd, Zn, and $\mathrm{Pb}$ was almost entirely due to an increase in soil $\mathrm{pH}$. The metal availability (assessed with a $0.01 \mathrm{M} \mathrm{CaCl}$ extraction) was similar in control and biocharamended soils at a given $\mathrm{pH}$, but the biochar increased the acid-neutralizing capacity of the soil, effectively buffering the soil against future decreases in $\mathrm{pH}$ 
and preventing the leaching of metals. Separating the immobilization of metals due to sorption on the biochar surface from the ( $\mathrm{pH}$ mediated) effect of sorption on the soil surface is difficult but has been attempted by Rees et al. (2014a) who constructed a two-column experiment. Leachate was circulated sequentially through columns containing contaminated soil and biochar separately to determine the relative sorption of $\mathrm{Cu}, \mathrm{Pb}$, and $\mathrm{Zn}$ on both the biochar and the soil.

Biochars are likely to be more effective in soils where contaminants are more bioavailable. Superior AC effectiveness in reducing mercury and methylmercury bioavailability has been reported in sediments with lower native sediment-water partition coefficients than in sediments where the contaminants were already tightly bound (Gilmour et al., 2013). Gomez-Eyles et al. (2013b) reported much higher bioavailability reductions in PCB-impacted sediments after amendment with AC than biochar. These higher reductions in bioavailability were related to the higher sorption capacity of the ACs that were generally 1 to 2 orders of magnitude higher than the biochars. As the sorptive capacity of the sediments used in that study was already high before amendment, it was concluded that the biochars did not provide a sufficient enhancement of the sorptive properties of the native sediment, whereas the AC did. However, in other sediments or soils where the native bioavailability is lower to start off with (e.g., soils with low native organic carbon and black carbon contents) the addition of biochar amendments will have a larger impact on the sorptive capacity of the soil with a subsequent reduction in HOC bioavailability. Similarly for heavy metals, biochars have been shown to be highly effective in reducing metal mobility in sandy-acidic mine soils (Sizmur et al., 2011e), but smaller bioavailability reductions have been observed in calcerous soils where the metals are already strongly bound (Gomez-Eyles et al., 2011).

\section{Summary}

The methods used to assess the mobility of contaminants in soils are becoming increasingly sophisticated, and there is a general move toward assessing the mobility of contaminants in biochar-remediated soil with passive samplers instead of chemical extractions. Biochar applied to soil has been shown to reduce contaminant mobility in leachate, porewaters, water extractions, $0.01 \mathrm{M} \mathrm{CaCl}_{2}$ extractions, EDTA extractions, and cyclodextrin extractions. Mixing biochar with soil also enables researchers to understand the interactions between biochars and soil and elucidate indirect mechanisms for biochar-reducing contaminant mobility. For example, the application of biochar to soil often increases the $\mathrm{pH}$, which increases the $\mathrm{pH}$-dependent cation exchange capacity of soils and results in higher metal removal from the soil solution.

\section{Bioassays}

Bioassays (or biological assays) employ organisms in determining the availability, uptake, and toxicity of contaminants in soils. Experiments to assess the effect of biochar on soil contaminant remediation often involve introducing organisms into contaminated soil mixed with biochar (alongside a biochar-free control soil). The growth of the organism, the uptake of contaminants by the organism, or the symptoms of toxicity expressed by the organism are then assessed. Bioassays add another layer of complexity to the systems studied in both batch sorption experiments and soil-biochar incubations. The processes that can be captured by 
bioassays include (i) the desorption of contaminants from the soil surface, (ii) the adsorption of contaminants on the surface of the biochar, (iii) the uptake of contaminants by an organism, and (iv) the transport of contaminants to a site of toxic action. Bioassays are therefore better able to predict the effect of biochar on the bioavailability and toxicity of contaminants in soils than soil-biochar incubations.

The majority of bioassays conducted to demonstrate a reduction in contaminant bioavailability after biochar application use either plants or earthworms as test organisms. Both plants and earthworms are at the base of the terrestrial food chain. Therefore, reducing the uptake of contaminants to plants and earthworms minimizes trophic transfer to humans and predatory mammals and birds (Armitage and Gobas, 2007; Peralta-Videa et al., 2009). This is particularly the case for contaminants that biomagnify through food webs (e.g., methylmercury and PCBs).

\section{Earthworms}

Earthworms are important soil organisms because they regulate soil structure, accelerate the rate of organic matter decomposition, and increase nutrient availability to plants. Earthworms are therefore considered keystone species and ecosystem engineers (Jones et al., 1994; Jouquet et al., 2006). It is for these reasons that it is important to reduce the bioavailability of contaminants to earthworms to below a level where these ecosystem services are not significantly affected. Furthermore, because earthworms are easy to culture in laboratories, have intimate contact with the soil, and do not require special permits for their use in ecotoxicology, they are excellent test species for bioassays.

Significant reductions in earthworm bioaccumulation have been reported after biochar amendment for a number of contaminants including PAHs and $\mathrm{Cu}$ (Gomez-Eylesetal., 2011), PCBs (Denyesetal., 2012), Pb(Caoetal., 2011), atrazine (Cao et al., 2011; Wang et al., 2014), and hexachlorobenzene (Song et al., 2012). However, other studies have found no effect or very modest reductions in bioaccumulation. For example, Andrade et al. (2014) found biochar amendments had no effect or slightly increased dieldrin and 4,4'-DDT bioaccumulation in E. fetida. The same study reported drops in 4,4'-DDD (dichlorodiphenyldichloroethane) and 4,4'DDE (dichlorodiphenyldichloroethylene) bioaccumulation, but these reductions were generally lower than those achieved by compost amendments. Similarly, Denyes et al. (2013) found significant reductions in PCB bioaccumulation after manually mixing AC into the soil, but not for biochars. However, significant reductions were observed for both amendments when mechanically mixing the carbons into the soils for $24 \mathrm{~h}$. Gomez-Eyles et al. (2011) reported significant reductions in $\mathrm{Cu}$ mobility after biochar application, but not for $\mathrm{As}, \mathrm{Cd}, \mathrm{Co}, \mathrm{Ni}$, and $\mathrm{Zn}$. These contrasting results suggest the success of biochar amendments is likely to be biochar and soil specific. Both the sorptive quality and quantity of the biochar, and the native bioavailability of the contaminants in the receiving soil, will ultimately control whether the amendment is effective. Other factors like the soil properties (e.g., organic matter content), the mixing regime, and even the earthworm species will also influence how effective biochar is in reducing earthworm bioaccumulation. Wang et al. (2014) reported larger reductions in atrazine bioaccumulation for endogeic earthworms (Metaphire guillelmi) that live and feed in soil than for epigeic earthworms (Eisenia fetida) that live and feed 
in the soil litter. It was hypothesized that biochar was particularly effective at reducing atrazine absorption through the earthworm gut.

Despite reducing bioaccumulation, minor toxic effects of biochar on earthworm health have been reported. Gomez-Eyles et al. (2011) recorded a reduction in earthworm weight in a hardwood-derived biochar-amended soil contaminated with PAHs and metals relative to an unamended soil. Decreased earthworm growth rate was also observed by Jakob et al. (2012) after addition of ACs to a PAHcontaminated soil. Earthworms feed by allowing dissolved organic molecules to diffuse across their gut wall. Therefore, biochar may also reduce nutrient absorption in the earthworm gut. The more effective the biochar is at adsorbing organic molecules, the greater impact this is likely to have on earthworm growth rates.

Earthworms are known to ingest biochar (Lehmann et al., 2011) and act as mixing and dispersing agents for biochar in soils (Ameloot et al., 2013), and may therefore benefit remediation. Concurrently, the inoculation of earthworms into contaminated soils has the potential to become a commonly used practice during land remediation and restoration (Butt, 1999; Sizmur et al., 2011a). However, in the absence of biochar, earthworms can increase contaminant mobility in soils through their feeding, burrowing, and casting activities (Sizmur et al., 2011b; Sizmur et al., 2011d). Therefore, it is prudent to investigate whether earthworm activity in biochar-amended soils increases or decreases the mobility of metals. Sizmur et al. (2011e) inoculated L. terrestris earthworms into a former mine soil contaminated with $\mathrm{Cu}, \mathrm{Pb}$, and $\mathrm{Zn}$ after biochar amendment and found that the earthworms had no significant effect on the metal mobility. However, biochar application reduced the concentrations of water soluble metals by $>95 \%$, so any earthworm mediated increase in mobility may have been buffered by this very effective biochar.

\section{Plants}

Reductions in both organic and inorganic contaminant bioaccumulation have been reported in different plant species (e.g., Cucurbita pepo, Brassica napus and Zea mays) after biochar amendment (Brennan et al., 2014b; Denyes et al., 2012; Denyes et al., 2013; Houben et al., 2013a). However, the success of the biochar treatment is likely to depend on the factors previously discussed for earthworms (biochar sorpitive capacity, bioavailability of contaminants in soil before application, species selection, and biochar mixing regime). For example Denyes et al. (2013) found that the biochar amendment was only effective at reducing PCB bioaccumulation in C. pepo after vigorously mixing the biochar into the soil, and Hartley et al. (2009) did not observe a substantial alteration in As uptake into Miscanthus foliage following biochar application.

As well as reducing contaminant bioaccumulation by lowering bioavailability, biochar has also been found to increase germination rates and reduce the phytotoxicity of contaminants to plants species. During early seedling establishment, Beesley et al. (2014) found that the germination and root length of Lolium perenne cultured in porewaters extracted from a former mine soil contaminated with As, $\mathrm{Cd}, \mathrm{Cu}, \mathrm{Pb}$, and $\mathrm{Zn}$ was increased if the soil was first remediated by application of a biochar produced from the pyrolysis of orchard residues. Germination and root elongation of Lepidium sativum in contaminated sediment-soil mixtures polluted with both organic and inorganic contaminants was also improved by biochar 
amendment (Jośko et al., 2013). Brennan et al. (2014b) showed an increase in maize (Zea mays) biomass and chlorophyll content after biochar produced form pine woodchip and maize stubble was added to soils contaminated with PAHs, As, $\mathrm{Cu}$, and $\mathrm{Zn}$. Furthermore, biochar promoted the development of fine maize roots, crucial to water and nutrient uptake in $\mathrm{Cu}$ - and As-contaminated soil (Brennan et al., 2014a). Houben et al. (2013a) found that the availability of $\mathrm{Cd}, \mathrm{Zn}$, and $\mathrm{Pb}$ to Brassica napus decreased with increasing biochar applications. Applications of $1 \%$ resulted in $100 \%$ mortality after $12 \mathrm{wk}$, but the $10 \%$ amended soils produced larger plants with lower metal concentrations than the $5 \%$ amended soils. The authors suggest that $B$. napus can be grown as an energy crop on contaminated land and the biomass pyrolyzed and returned to the soil to benefit remediation.

The introduction of plants to contaminated land helps to bind the soil and prevent erosion (Tordoff et al., 2000). Subsequently, by establishing a vegetative cover the risk of pollutants migrating off site to water courses is reduced (Robinson et al., 2009). There are several authors that report little or no increase in plant growth after biochar amendment alone, but an increase in plant growth when biochar is added alongside organic or inorganic fertilizers that cannot be explained by the fertilizer alone (Chan et al., 2007; Steiner et al., 2007; Van Zwieten et al., 2010; Yamato et al., 2006). Biochars, as well as immobilizing contaminants, can also affect the bioavailability of nutrients in soils. While some biochars can release nutrients into soils, it is often the case that nutrients in soil sorb to the biochar, which is why only modest increases in plant growth are observed after addition of biochar to unfertilized soils. When biochar is applied alongside fertilizer the biochar can reduce leaching and increase the efficiency of the fertilizers. In contaminated soils, biochar is able to reduce the toxicity of contaminated soil, improve plant germination rates, and reduce plant uptake of pollutants, but it can only increase plant biomass in soils where fertilizer is also applied (Fig. 4). Therefore, when applying biochar to remediate and revegetate contaminated soils it is recommended to apply in combination with fertilizer (Beesley et al., 2014; Beesley et al., 2011; Karami et al., 2011; Sizmur et al., 2011e).

\section{Summary}

Bioassays to assess the effect of biochar applications on the bioavailability of contaminants have chiefly employed earthworms and plants as test organisms. Some bioassays have revealed reductions in the uptake of metals by earthworms and plants, but several studies have failed to register significant reductions. These contrasting outcomes may be due to differences in the biochar sorpitive capacity, the bioavailability of contaminants in soil before application, species selection, and the biochar mixing regime. Biochar has been found to increase growth and reduce the symptoms of toxicity in plants but, contrastingly, reduce the growth of earthworms. Both plants and earthworms may benefit contaminated soil remediation because of erosion prevention and enhanced mixing of biochar and soil.

\section{Field Experiments}

Field experiments offer perhaps the best opportunity to test the performance of a biochar for the remediation of a contaminated soil in a measured and realistic way. By applying biochar to contaminated soils in situ, experiments are exposed to prevailing ambient conditions rather than the temporally homogenous 


\section{Contaminated soil only}

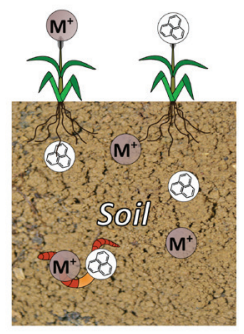

\section{Contaminated} soil and biochar

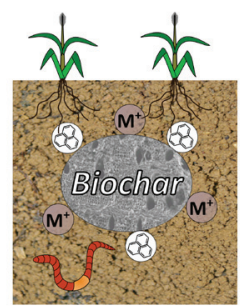

2. Contaminated soil and fertilizer

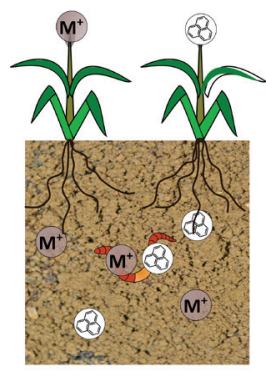

4. Soil, biochar, and fertilizer

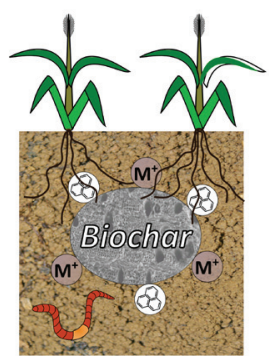

Fig. 4. Conceptual model of biochar and fertilizer applications to contaminated soils. When soil is unamended (1.) contaminants are taken up into plant and earthworm tissues. Fertilizer applications (2.) increase plant growth but not contaminant bioavailability. Biochar application (3.) reduces contaminant bioavailability, but only by adding biochar and fertilizer simultaneously (4.) is plant growth maximized while reducing the bioavailability of contaminants to plants and earthworms.

\section{$M^{+}=$Metal cation 28 = Polycyclic aromatic hydrocarbon}

conditions provided by micro- and mesoscale laboratory and glasshouse trials. Biochar is incorporated into soils (or applied to the surface) in plots of a given area and then compared with biochar-free control plots (Bian et al., 2014). To account for the inherent variability of soils (particularly at contaminated sites, which are often more heterogeneous than arable soils), good statistical design must be employed (i.e., replication, randomization, and blocking) (Welham et al., 2014). To avoid cross-contamination, buffer strips are included between experimental plots (Hammond et al., 2013). Field experiments are usually costly to conduct, and the number of treatments that can be tested is often more limited than in laboratory experiments. Therefore, field experiments tend to only trial the use of biochars that have already undergone laboratory testing (i.e., batch sorption, soil incubations, or bioassays). Measurements can be made in each plot of a field experiment over time to test the performance of the remediation. For example, vegetation, invertebrates, porewater, or leachate can be surveyed or sampled, often simultaneously with climatic data collected from a local weather station.

\section{Lessons Learned from the Field Application of Activated Carbon to Contaminated Sediments}

For the reasons listed above, there are very few examples of field experiments in which biochar has been applied to contaminated soils, particularly those contaminated with organic pollutants. However, much can be learned from previous experiments that have assessed the potential for AC to remediate 
contaminated sediments. For example, field pilots with AC have shown that it will take the carbon amendments several years to be fully effective in the field, as the mass transfer of HOCs from native organic matter onto introduced carbons can be a slow process, especially for the bulkier and more hydrophobic HOCs (Beckingham and Ghosh, 2011). Initial reductions in the field may therefore be more modest than predicted from initial well-mixed batch sorption studies; however, valuable information from AC pilot studies will enhance the effectiveness of biochars in future soil field pilots for HOCs. For example, the benefits of using the smallest particle size carbon practical (Zimmerman et al., 2005) and mixing the biochar into the soil effectively to speed up HOC mass transfer (Cho et al., 2009) will be equally applicable to biochar as they are for AC. Denyes et al. (2013) found no significant reductions in PCB bioaccumulation after manually mixing biochars and AC into soil, but did find significant reductions when the amendments were mechanically mixed into the soil for $24 \mathrm{~h}$. Benthic organisms have been shown to help with this mixing in a process called bioturbation (Sun and Ghosh, 2007), so it likely that a rich soil fauna (e.g., earthworms) would also enhance biochar performance. The kinetics of mass transfer could be slower in soils than sediments, as mass transfer occurs through the aqueous phase and will therefore be minimal when the soil is dry. Therefore, keeping soils as water saturated as possible will also help contaminant transfer onto the biochar.

\section{Biochar Applications to Contaminated Soils in the Field}

Unlike organic contaminants, there are a few examples of field trials that use biochar to remediate metal contaminated soils. A suite of sequential cropping field experiments under a rice-wheat rotation that were designed to test the effect of biochar on the uptake of $\mathrm{Cd}$ from contaminated paddy fields in China have been recently reported (Bian et al., 2013). These were conducted in response to high levels of $\mathrm{Cd}$ found in rice from the region. Wheat straw biochar reduced the concentration of Cd in rice (Bian et al., 2014; Cui et al., 2011) and wheat (Cui et al., 2012) up to $3 \mathrm{yr}$ after applications of 20 to $40 \mathrm{t} / \mathrm{ha}$. The biochar increased the soil $\mathrm{pH}$, reduced the $\mathrm{CaCl}_{2}$ extractable $\mathrm{Cd}$, and increased the soil organic carbon. The mass transfer of $\mathrm{Cd}$ from the soil to the biochar surfaces may have been faster in this experiment than experiments in arid environments because of the annual flooding inherent to rice paddies.

Beesley and Dickinson (2011) used a moderately polluted urban garden soil in the United Kingdom to study the impacts of a wood-derived biochar applied over the surface of the soil on the concentrations of metals, soluble $\mathrm{C}$, and $\mathrm{N}$ in porewater at depths of 25,50, and $75 \mathrm{~cm}$ below the soil surface. Their aim was to determine whether dissolved $C$ from the weathering of biochar in situ, over the course of $1 \mathrm{yr}$, impacted on metal leaching and export from the soil profile by association of soluble $\mathrm{C}$ complexes. Soil was circumneutral in $\mathrm{pH}, 6 \%$ organic matter, and up to $30,170,360$, and $450 \mathrm{mg} / \mathrm{kg} \mathrm{Cd}, \mathrm{Cu}, \mathrm{Zn}$, and $\mathrm{Pb}$, respectively. Biochar caused similar increases in soluble carbon within the soil profile, as a comparative greenwaste compost amendment, but greatly increased As solubility. It was noted that the effects of the surface application of biochar, in common with greenwaste compost, only had an impact on the metal-organic carbon dynamics in the top $25 \mathrm{~cm}$ of soil profile, while lower depths were largely unaffected. 


\section{Summary}

Field experiments enable researchers to demonstrate technology to practitioners and are not often used to unravel mechanisms or investigate hypotheses. Research on the application of biochar for soil remediation is in its infancy and there are only a few field experiments that specifically trial the application of biochar for this purpose. A suite of field experiments to remediate Cd-contaminated paddy fields in China have demonstrated that biochar can reduce $\mathrm{Cd}$ uptake by wheat. However, an experiment in the United Kingdom has demonstrated that biochar application to the surface of contaminated urban soils can increase the solubility of As deeper in the soil profile. Because research into the application of AC to contaminated sediments has progressed further than biochar applications to contaminated soils, lesson can be transferred and used to make recommendations. These recommendations include (i) reducing bicohar particle size as much as possible, (ii) thoroughly mixing biochar with soil mechanically or by encouraging earthworm activity, and (iii) keeping soil moisture as elevated as possible.

\section{Implications for the Application of Biochar to Uncontaminated Agricultural Soils}

Biochar inherently contains varying levels of organic pollutants such as PAHs, dioxins, or furans which are produced during pyrolysis (Garcia-Perez, 2008; Hale et al., 2012) and metals which are present in contaminated source material and concentrated after pyrolysis (Hossain et al., 2010; Kim et al., 2012; Matsuura et al., 2009). Therefore, the application of biochar to agricultural soil could potentially carry a significant risk to human health by contaminating soils used for growing crops or keeping livestock, unless appropriate measures are taken to minimize these risks.

\section{Organic Contaminants Associated with Biochar}

As discussed previously, biochar is particularly effective at adsorbing and sequestering organic contaminants (Beesley et al., 2010; Denyes et al., 2012; Gomez-Eyles et al., 2013b). As a result, enhanced sorption of hydrophobic organic compounds such as PAHs could decrease microbial mineralization by decreasing bioavailability to degrading organisms (Quilliam et al., 2013b; Rhodes et al., 2008, 2010; Song et al., 2012; Xia et al., 2010; Xin et al., 2014). This sorption is generally viewed as positive as it will result in reduced toxic effects by the contaminant and minimize HOC transfer up the food chain. However, when soil is contaminated with readily degradable or volatile organic compounds that could dissipate out of soils naturally (e.g., aliphatic hydrocarbons, low molecular weight PAHs, and chlorinated solvents), sorption to biochar may extend contaminant life time in the soil by reducing mineralization rates (Rhodes et al., 2008). On the other hand, some studies have found increasing degradation rates after biochar amendment (Qin et al., 2013; Sneath et al., 2013). This increased degradation is likely to be a consequence of biochar reducing the immediate toxicity of the freshly spiked contaminant to degrading bacteria. If contaminant bioavailability is not the limiting factor, the addition of biochar can help by reducing the risk of overloading the soil's biodegradation capacity (Bushnaf et al., 2011; Meynet et al., 2014). More recent research points toward coupling the reduced risk provided by contaminant sorption to 
the biochar, with increased degradation by coating the carbon with contaminant degrading biofilms (Chen et al., 2012). The biochar surface could provide a source of high contaminant concentration for the organisms to feed on, and the biofilm would provide a suitable habitat for the bacterial community. Successful results have already been reported using this technology in ACs to enhance PCB dechlorination in impacted sediments (Kjellerup et al., 2014; Payne et al., 2013). However, a recent study of field-aged biochar in agricultural soil has demonstrated minimal natural colonization of the external (and internal) surfaces of wood-derived biochar (Quilliam et al., 2013a). Survival of a biofilm on biochar surface may therefore not be long enough to degrade contaminants because of the limitation of C in this particular niche (Quilliam et al., 2013a).

Despite having a strong sorption capacity for HOCs, biochar does not always decrease leaching, and in particular situations could actually increase the risk of HOC leaching if the application of biochar results in the release of considerable amounts of dissolved organic carbon (DOC) (Quilliam et al., 2013b). The sorption of HOCs to DOC and small pyrolyzed dust particles could also have other important downstream implications, (e.g., earthworm ingestion and subsequent bioaccumulation in food chains). Dissolved organic carbon release decreases with increasing biochar pyrolysis temperature and is also lower for hardwood source materials than grasses (Mukherjee and Zimmerman, 2013). This is consistent with recommendations given by Hale et al. (2012) that lower PAH and dioxin concentrations in biochars can be achieved by using woody source materials and pyrolyzing slowly (for several hours) at higher temperatures (between 500 and $600^{\circ} \mathrm{C}$ ). Therefore, careful selection of source material and pyrolysis conditions will help to reduce the risk of HOC pollution when applying biochar to uncontaminated soils.

\section{Inorganic Contaminants in Biochar}

Certain source materials can contain significant levels of indigenous heavy metals (e.g., sewage sludge or preservative-treated waste wood), and as metals with high boiling points (e.g., $\mathrm{Pb}, \mathrm{Ni}, \mathrm{Cu}, \mathrm{Zn}$, and $\mathrm{Cr}$ ) are rarely transferred into bio-oil or become volatilized (except $\mathrm{Hg}, \mathrm{As}, \mathrm{Cd}$, and $\mathrm{Se}$ ) during pyrolysis or combustion (Van Wesenbeeck et al., 2014), metal enrichment of biochar is inevitable (Hossain et al., 2010; Kim et al., 2012; Matsuura et al., 2009). Biochars produced from waste materials are inherently variable both spatially and temporally because of the variability in the composition of the source material. Yoshida and Antal Jr. (2009) found that biochar produced by pyrolyzing sewage sludge from a water treatment plant on the island of Oahu, Hawaii, contained metal concentrations below that preventing application to land. However, biochar produced from a nearby treatment plant on the same island contained elevated concentrations of $\mathrm{Zn}, \mathrm{Mo}$, and $\mathrm{Cr}$ that prevented their legal application to soils in Hawaii according to USEPA threshold values (Van Wesenbeeck et al., 2014). However, when cherry tomatoes were grown in soils amended with biochar produced from sewage sludge, the fruit was found to contain metal concentrations considerably lower than the Australian maximum permitted concentrations in food (Hossain et al., 2010). These findings indicate that although some biochars may contain elevated concentrations of metals, their bioavailability to plants is likely to be very low.

The consequences of applying biochar produced from contaminated waste wood source material are only now becoming evident (Lucchini et al., 2014a), 
with implications for metal bioavailability and plant growth. Streams of waste wood, containing even small levels of preservative-treated wood used to produce biochar destined for soil application could pose a risk to soil quality and crop production, and pose a considerable environmental risk (Jones and Quilliam, 2014; Omil et al., 2007; Praharaj et al., 2002). Biochar made from waste wood source materials containing varying levels of contaminated timber can increase concentrations of soil available $\mathrm{Cu}$, leading to changes in soil microbial community dynamics and uptake by crop plants. However, greater uptake does not necessarily result in a reduction of plant biomass. Subsequently, a thorough analysis of the source material intended for biochar production is critical before land application to avoid increasing the pollutant load of the soil or the availability or mobility of indigenous contaminants (Lucchini et al., 2014b; Madrid et al., 2007; Pérezde-Mora et al., 2006). Recently, it has been demonstrated that biochar produced from waste forest residue contains an inherently low metal content (Lucchini et al., 2014b), and although biochar made from this source material caused small changes to metal fractionation, total metal concentrations in both soil and plant tissue remained unaltered.

\section{Pesticides}

In an agricultural context, the property of biochar that gives it such great potential for remediating contaminated sites (i.e., readily binding organic pollutants and heavy metals) can also significantly influence pesticide behavior in agricultural soils (Eibisch et al., 2015; Kookana, 2010). Sorption may decrease the efficacy of soil-applied agrochemicals by influencing their bioavailability and susceptibility to leaching, while the implications of biochar on pesticide behavior, particularly in the longer term, remains poorly understood (Cabrera et al., 2014). Biochar can induce the rapid and strong sorption of herbicides, which can reduce leaching, mineralization, and efficiency (Graber et al., 2012; Reid et al., 2013). Reduced leaching must be balanced with increased soil residence time since sorption to biochar may limit herbicide availability to microbial communities and suppress biodegradation in soils (Mello De Capitani et al., 2007). Evidence suggests that the effect of biochar on herbicide behavior is dependent on pyrolysis conditions, source material, and soil type (Sun et al., 2012b). Consequently, the longer term effects of biochar on pesticide sorption are unclear. Contrasting studies report either decreased sorption of herbicides by field-aged biochar (Martin et al., 2012) or the same effect as fresh biochar on sorption and microbial mineralization (Jones et al., 2011). Biochar application to soil, therefore, could potentially reduce the dissipation of foliar-applied pesticides and decrease the risk of human exposure and environmental contamination, but importantly could significantly affect the efficacy of soil-applied herbicides.

\section{The Human Health Implications of Applying Biochar to Agricultural Soils}

Although still poorly understood, there are several public health concerns associated with amending soil with biochar or wood ash. Breathing in small particles of biochar, either during its production or application, or after wind erosion from soil, can cause the serious respiratory disease pneumoconiosis (Mello De Capitani et al., 2007). The potential for biochar or wood ash dust to contain 
considerable concentrations of metals further increases the risk to human health (Uski et al., 2012). Because of the difficulty in determining whether a source material is contaminated there is an urgent need for an improved understanding of the public health risk of applying biochar or wood ash to land, including irritation to eyes and mucous membranes by airborne pollutants (Vassilev et al., 2013). One potential strategy to lower human exposure is the pelletization of biochar and wood ash which would greatly reduce airborne particulate loss both pre- and postspreading, and may result in a better slow-release fertilizer (Gómez-Rey et al., 2012). However, this is likely to increase costs.

Contaminants applied to soils in biochar could also leach through soils and enter groundwater, or be ingested by soil organisms and biomagnify through food webs, causing toxicity at higher tropic levels. However, the greatest exposure risk comes from consuming crop plants that have accumulated considerable concentrations of metals in their edible parts. The potential for human exposure to toxic concentrations of metals will depend on the capacity for root uptake by individual crop species and the ability of the plant to sequester the contaminant without adversely effecting its growth. Uninformed growing (or grazing) of crops in soil amended with biochar made from a contaminated source material could potentially deliver toxic levels of metals to the human food chain.

\section{Summary and Future}

A large number of published studies have used batch sorption techniques to compare biochars, model sorption of contaminants on the surface of biochar, and to elucidate the mechanisms responsible. Laboratory incubations of biochar with contaminated soils have employed a wide range of chemical methods to assess the availability or mobility of contaminants after incubation. They have also revealed indirect effects of biochar on contaminant availability by, for example, modifying soil $\mathrm{pH}$. Bioassays of earthworms or plants have been used in combination with chemical extractions to determine the impact of biochar on the bioavailability and bioaccessibility of contaminants in soil. The bioassays, in turn, must also consider the impact of the soil organisms themselves on the fate of contaminants sorbed to biochar surfaces. Only a small number of field trials have been conducted at contaminated sites to assess the use of biochar for soil remediation. Preliminary results are encouraging though, indicating that biochars are able to reduce metal contamination of edible crops grown on contaminated soils.

Because biochars are processed materials, they incur costs in time and energy to produce. Therefore, in the future biochars will be applied to land only if (i) they add value to agricultural systems (e.g., fertilizing crops), (ii) they reduce the prevalence of contaminants (e.g., remediating soils or safely disposing of contaminated feedstock), and (iii) they are as readily available and cost effective as other options (e.g., composts). A step back to consider the geographical and global context is required now that biochar research is maturing. There has been a technological and commercial push for biochar production without sufficient demand; in the future, biochars will only be produced where demand exists for them. Demand is likely to be for small batches of bespoke biochars designed for specific purposes, such as: 
- Co-application with fertilizers, to prevent rapid leaching of nutrients to from soils to waters

- $\quad$ Remediation of soils and waters where contamination poses a risk to the environment

- Disposal of low value or contaminated feedstocks

Circularizing the production of biochar is likely to form the focus on the next decade of research. Biochars will increasingly be produced in situ where and when there is a demand for them. This will reduce the burden of transportation of feedstocks to and biochars from centralized production facilities, and develop local-scale or mobile, easily operable facilities producing biochars on demand and blending them with other waste products. There will still be a need for demonstration trials to prove the value of biochars and assess the environmental risks incurred by producing biochars from mixed sources. This will ensure that biochars are deployed to their maximum potential environmental value.

\section{References}

Adams, R.G., R. Lohmann, L.A. Fernandez, J.K. MacFarlane, and P.M. Gschwend. 2007. Polyethylene devices: Passive samplers for measuring dissolved hydrophobic organic compounds in aquatic environments. Environ. Sci. Technol. 41:1317-1323. doi:10.1021/es0621593

Ameloot, N., E.R. Graber, F.G.A. Verheijen, and S. De Neve. 2013. Interactions between biochar stability and soil organisms: Review and research needs. Eur. J. Soil Sci. 64:379-390. doi:10.1111/ ejss.12064

Amonette, J.E. and S. Joseph. 2009. Characteristics of biochar: Microchemical properties. In: J. Lehmann and S. Joseph, editors, Biochar for environmental management: Science and technology. Earthscan, London. p. 33-52.

Andrade, N.A., et al. 2014. Utilizing thin-film solid-phase extraction to assess the effect of organic carbon amendments on the bioavailability of DDT and dieldrin to earthworms. Environ. Pollut. 185:307-313. doi:10.1016/j.envpol.2013.11.008

Armitage, J.M., and F.A.P.C. Gobas. 2007. A terrestrial food-chain bioaccumulation model for POPs. Environ. Sci. Technol. 41:4019-4025. doi:10.1021/es0700597

Bardos, P., J. Nathanail, and B. Pope. 2002. General principles for remedial approach selection. Land Contam. Reclam. 10:137-160. doi:10.2462/09670513.614

Beckingham, B., and U. Ghosh. 2011. Field-scale reduction of PCB bioavailability with activated carbon amendment to river sediments. Environ. Sci. Technol. 45:10567-10574. doi:10.1021/ es202218p

Beesley, L., and N. Dickinson. 2011. Carbon and trace element fluxes in the pore water of an urban soil following greenwaste compost, woody and biochar amendments, inoculated with the earthworm Lumbricus terrestris. Soil Biol. Biochem. 43:188-196. doi:10.1016/j. soilbio.2010.09.035

Beesley, L., et al. 2014. Assessing the influence of compost and biochar amendments on the mobility and toxicity of metals and arsenic in a naturally contaminated mine soil. Environ. Pollut. 186:195-202. doi:10.1016/j.envpol.2013.11.026

Beesley, L., and M. Marmiroli. 2011. The immobilisation and retention of soluble arsenic, cadmium and zinc by biochar. Environ. Pollut. 159:474-480. doi:10.1016/j.envpol.2010.10.016

Beesley, L., E. Moreno-Jiménez, and J.L. Gomez-Eyles. 2010. Effects of biochar and greenwaste compost amendments on mobility, bioavailability and toxicity of inorganic and organic contaminants in a multi-element polluted soil. Environ. Pollut. 158:2282-2287. doi:10.1016/j. envpol.2010.02.003

Beesley, L., E. Moreno-Jiménez, J.L. Gomez-Eyles, E. Harris, B. Robinson, and T. Sizmur. 2011. A review of biochars' potential role in the remediation, revegetation and restoration of contaminated soils. Environ. Pollut. 159:3269-3282. doi:10.1016/j.envpol.2011.07.023

Betts, A.R., N. Chen, J.G. Hamilton, and D. Peak. 2013. Rates and mechanisms of Zn2+ adsorption on a meat and bonemeal biochar. Environ. Sci. Technol. 47:14,350-14,357. 
Bian, et al. 2013. Biochar soil amendment as a solution to prevent Cd-tainted rice from China: Results from a cross-site field experiment. Ecol. Eng. 58:378-383. doi:10.1016/j.ecoleng.2013.07.031

Bian, R., et al. 2014. A three-year experiment confirms continuous immobilization of cadmium and lead in contaminated paddy field with biochar amendment. J. Hazard. Mater. 272:121-128. doi:10.1016/j.jhazmat.2014.03.017

Brennan, A., E.M. Jiménez, M. Puschenreiter, J.A. Alburquerque, and C. Switzer. 2014a. Effects of biochar amendment on root traits and contaminant availability of maize plants in a copper and arsenic impacted soil. Plant Soil 379:351-360. doi:10.1007/s11104-014-2074-0

Brennan, A., E. Moreno Jiménez, J.A. Alburquerque, C.W. Knapp, and C. Switzer. 2014b. Effects of biochar and activated carbon amendment on maize growth and the uptake and measured availability of polycyclic aromatic hydrocarbons (PAHs) and potentially toxic elements (PTEs). Environ. Pollut. 193:79-87. doi:10.1016/j.envpol.2014.06.016

Bucheli, T.D., and Ö. Gustafsson. 2000. Quantification of the soot-water distribution coefficient of PAHs provides mechanistic basis for enhanced sorption observations. Environ. Sci. Technol. 34:5144-5151. doi:10.1021/es000092s

Bushnaf, K.M., S. Puricelli, S. Saponaro, and D. Werner. 2011. Effect of biochar on the fate of volatile petroleum hydrocarbons in an aerobic sandy soil. J. Contam. Hydrol. 126:208-215. doi:10.1016/j.jconhyd.2011.08.008

Butt, K. 1999. Inoculation of earthworms into reclaimed soils: The UK experience. Land Degrad. Dev. 10:565-575. doi:10.1002/(SICI)1099-145X(199911/12)10:6<565::AID-LDR356>3.0.CO;2-K

Cabrera, A., L. Cox, K. Spokas, M. Hermosín, J. Cornejo, and W. Koskinen. 2014. Influence of biochar amendments on the sorption-desorption of aminocyclopyrachlor, bentazone and pyraclostrobin pesticides to an agricultural soil. Sci. Total Environ. 470-471:438-443. doi:10.1016/j.scitotenv.2013.09.080

Cabrera, A., et al. 2011. Comparative sorption and leaching study of the herbicides fluometuron and 4-chloro-2-methylphenoxyacetic acid (MCPA) in a soil amended with biochars and other sorbents. J. Agric. Food Chem. 59:12550-12560. doi:10.1021/jf202713q

Cao, X., and W. Harris. 2010. Properties of dairy-manure-derived biochar pertinent to its potential use in remediation. Bioresour. Technol. 101:5222-5228. doi:10.1016/j.biortech.2010.02.052

Cao, X., L. Ma, B. Gao, and W. Harris. 2009. Dairy-manure derived biochar effectively sorbs lead and atrazine. Environ. Sci. Technol. 43:3285-3291. doi:10.1021/es803092k

Cao, X., L. Ma, Y. Liang, B. Gao, and W. Harris. 2011. Simultaneous immobilization of lead and atrazine in contaminated soils using dairy-manure biochar. Environ. Sci. Technol. 45:48844889. doi:10.1021/es103752u

Chan, K., L. Van Zwieten, I. Meszaros, A. Downie, and S. Joseph. 2007. Agronomic values of greenwaste biochar as a soil amendment. Soil Res. 45:629-634. doi:10.1071/SR07109

Chen, B., M. Yuan, and L. Qian. 2012. Enhanced bioremediation of PAH-contaminated soil by immobilized bacteria with plant residue and biochar as carriers. J. Soils Sediments 12:13501359. doi:10.1007/s11368-012-0554-5

Chen, B., D. Zhou, and L. Zhu. 2008. Transitional adsorption and partition of nonpolar and polar aromatic contaminants by biochars of pine needles with different pyrolytic temperatures. Environ. Sci. Technol. 42:5137-5143. doi:10.1021/es8002684

Chen, X., et al. 2011. Adsorption of copper and zinc by biochars produced from pyrolysis of hardwood and corn straw in aqueous solution. Bioresour. Technol. 102:8877-8884. doi:10.1016/j.biortech.2011.06.078

Cho, Y.-M., et al. 2009. Field application of activated carbon amendment for in-situ stabilization of polychlorinated biphenyls in marine sediment. Environ. Sci. Technol. 43:3815-3823. doi:10.1021/es802931c

Cho, Y.-M., D. Werner, Y. Choi, and R.G. Luthy. 2012. Long-term monitoring and modeling of the mass transfer of polychlorinated biphenyls in sediment following pilot-scale in-situ amendment with activated carbon. J. Contam. Hydrol. 129-130:25-37. doi:10.1016/j.jconhyd.2011.09.009

Chun, Y., G. Sheng, C.T. Chiou, and B. Xing. 2004. Compositions and sorptive properties of crop residue-derived chars. Environ. Sci. Technol. 38:4649-4655. doi:10.1021/es035034w

Cornelissen, G., H. Rigterink, M.M.A. Ferdinandy, and P.C.M. van Noort. 1998. Rapidly desorbing fractions of PAHs in contaminated sediments as a predictor of the extent of bioremediation. Environ. Sci. Technol. 32:966-970. doi:10.1021/es9704038

Cui, L., L. Li, A. Zhang, G. Pan, D. Bao and A. Chang. 2011. Biochar amendment greatly reduces rice $\mathrm{Cd}$ uptake in a contaminated paddy soil: $\mathrm{A}$ two-year field experiment. BioResources 6:2605-2618. 
Cui, L., et al. 2012. The reduction of wheat Cd uptake in contaminated soil via biochar amendment: A two-year field experiment. BioResources 7:5666-5676. doi:10.15376/biores.7.4.5666-5676

Dechene, A., I. Rosendahl, V. Laabs, and W. Amelung. 2014. Sorption of polar herbicides and herbicide metabolites by biochar-amended soil. Chemosphere 109:180-186.

Denyes, M.J., V.S. Langlois, A. Rutter, and B.A. Zeeb. 2012. The use of biochar to reduce soil PCB bioavailability to Cucurbita pepo and Eisenia fetida. Sci. Total Environ. 437:76-82. doi:10.1016/j. scitotenv.2012.07.081

Denyes, M.J., A. Rutter, and B.A. Zeeb. 2013. In situ application of activated carbon and biochar to $\mathrm{PCB}$-contaminated soil and the effects of mixing regime. Environ. Pollut. 182:201-208. doi:10.1016/j.envpol.2013.07.016

Dong, X., L.Q. Ma, Y. Zhu, Y. Li, and B. Gu. 2013. Mechanistic investigation of mercury sorption by Brazilian pepper biochars of different pyrolytic temperatures based on X-ray photoelectron spectroscopy and flow calorimetry. Environ. Sci. Technol. 47:12156-12164. doi:10.1021/ es4017816

Eibisch, N., R. Schroll, R. Fuß, R. Mikutta, M. Helfrich, and H. Flessa. 2015. Pyrochars and hydrochars differently alter the sorption of the herbicide isoproturon in an agricultural soil. Chemosphere 119:155-162. doi:10.1016/j.chemosphere.2014.05.059

Farrell, M., G. Rangott, and E. Krull. 2013. Difficulties in using soil-based methods to assess plant availability of potentially toxic elements in biochars and their feedstocks. J. Hazard. Mater. 250-251:29-36. doi:10.1016/j.jhazmat.2013.01.073

Garcia-Perez, M. 2008. The formation of polyaromatic hydrocarbons and dioxins during pyrolysis: A review of the literature with descriptions of biomass composition, fast pyrolysis technologies and thermochemical reactions. Washington State Univ., Pullman, WA.

Ghosh, U., et al. 2014. Passive sampling methods for contaminated sediments: Practical guidance for selection, calibration, and implementation. Integr. Environ. Assess. Manage. 10:210-223. doi:10.1002/ieam.1507

Ghosh, U., R.G. Luthy, G. Cornelissen, D. Werner, and C.A. Menzie. 2011. In situ sorbent amendments: A new direction in contaminated sediment management. Environ. Sci. Technol. 45:1163-1168. doi:10.1021/es102694h

Gilmour, C.C., et al. 2013. Activated carbon mitigates mercury and methylmercury bioavailability in contaminated sediments. Environ. Sci. Technol. 47:13001-13010. doi:10.1021/es4021074

Gomez-Eyles, J., L. Beesley, E. Moreno-Jiménez, U. Ghosh, and T. Sizmur. 2013a. The potential of biochar amendments to remediate contaminated soils. In: N. Ladygina and F. Rineau, editors, Biochar and Soil Biota. CRC Press, Boca Raton, FL.

Gomez-Eyles, J., C.D. Collins, and M.E. Hodson. 2010. Assessing the capability of butanol, cyclodextrin and tenax extractions to predict polycyclic aromatic hydrocarbon bioavailability: Are accumulation bioassays valid reference systems? Environ. Pollut. 158:278-284. doi:10.1016/j. envpol.2009.07.012

Gomez-Eyles, J.L., M.T.O. Jonker, M.E. Hodson, and C.D. Collins. 2012. Passive samplers provide a better prediction of $\mathrm{PAH}$ bioaccumulation in earthworms and plant roots than exhaustive, mild solvent, and cyclodextrin extractions. Environ. Sci. Technol. 46:962-969. doi:10.1021/ es203499m

Gomez-Eyles, J.L., C. Yupanqui, B. Beckingham, G. Riedel, C. Gilmour, and U. Ghosh. 2013. Evaluation of Biochars and activated carbons for in situ remediation of sediments impacted with organics, mercury, and methylmercury. Environ. Sci. Technol. 47:13,721-13,729.

Gomez-Eyles, J.L., T. Sizmur, C.D. Collins, and M.E. Hodson. 2011. Effects of biochar and the earthworm Eisenia fetida on the bioavailability of polycyclic aromatic hydrocarbons and potentially toxic elements. Environ. Pollut. 159:616-622. doi:10.1016/j.envpol.2010.09.037

Gomez-Eyles, J.L., C. Yupanqui, B. Beckingham, G. Riedel, C. Gilmour, and U. Ghosh. 2013b. Evaluation of biochars and activated carbons for in situ remediation of sediments impacted with organics, mercury, and methylmercury. Environ. Sci. Technol. 47:13721-13729. doi:10.1021/ es403712q

Gómez-Rey, M.X., M. Madeira, and J. Coutinho. 2012. Wood ash effects on nutrient dynamics and soil properties under Mediterranean climate. Ann. For. Sci. 69:569-579. doi:10.1007/ s13595-011-0175-y

Graber, E., L. Tsechansky, Z. Gerstl, and B. Lew. 2012. High surface area biochar negatively impacts herbicide efficacy. Plant Soil 353:95-106. doi:10.1007/s11104-011-1012-7

Hale, S.E., et al. 2013. Short-term effect of the soil amendments activated carbon, biochar, and ferric oxyhydroxide on bacteria and invertebrates. Environ. Sci. Technol. 47:8674-8683. 
Hale, S.E., et al. 2012. Quantifying the total and bioavailable polycyclic aromatic hydrocarbons and dioxins in biochars. Environ. Sci. Technol. 46:2830-2838. doi:10.1021/es203984k

Hammond, J., S. Shackley, M. Prendergast-Miller, J. Cook, S. Buckingham, and V.A. Pappa. 2013. Biochar field testing in the UK: Outcomes and implications for use. Carbon Manage. 4:159-170. doi:10.4155/cmt.13.3

Hartley, W., N.M. Dickinson, P. Riby, and N.W. Lepp. 2009. Arsenic mobility in brownfield soils amended with green waste compost or biochar and planted with Miscanthus. Environ. Pollut. 157:2654-2662. doi:10.1016/j.envpol.2009.05.011

Harvey, O.R., B.E. Herbert, R.D. Rhue, and L.-J. Kuo. 2011. Metal interactions at the biochar-water interface: Energetics and structure-sorption relationships elucidated by flow adsorption microcalorimetry. Environ. Sci. Technol. 45:5550-5556. doi:10.1021/es104401h

Hossain, M.K., V. Strezov, K. Yin Chan, and P.F. Nelson. 2010. Agronomic properties of wastewater sludge biochar and bioavailability of metals in production of cherry tomato (Lycopersicon esculentum). Chemosphere 78:1167-1171. doi:10.1016/j.chemosphere.2010.01.009

Houba, V.J.G., E.J.M. Temminghoff, G.A. Gaikhorst, and W. van Vark. 2000. Soil analysis procedures using $0.01 \mathrm{M}$ calcium chloride as extraction reagent. Commun. Soil Sci. Plant Anal. 31:1299-1396. doi:10.1080/00103620009370514

Houben, D., L. Evrard, and P. Sonnet. 2013a. Beneficial effects of biochar application to contaminated soils on the bioavailability of $\mathrm{Cd}, \mathrm{Pb}$ and $\mathrm{Zn}$ and the biomass production of rapeseed (Brassica napus L.). Biomass Bioenergy 57:196-204. doi:10.1016/j.biombioe.2013.07.019

Houben, D., L. Evrard, and P. Sonnet. 2013b. Mobility, bioavailability and pH-dependent leaching of cadmium, zinc and lead in a contaminated soil amended with biochar. Chemosphere 92:1450-1457. doi:10.1016/j.chemosphere.2013.03.055

Jakob, L., et al. 2012. PAH-sequestration capacity of granular and powder activated carbon amendments in soil, and their effects on earthworms and plants. Chemosphere 88:699-705. doi:10.1016/j.chemosphere.2012.03.080

Jin, H., S. Capareda, Z. Chang, J. Gao, Y. Xu, and J. Zhang. 2014. Biochar pyrolytically produced from municipal solid wastes for aqueous $\mathrm{As}(\mathrm{V})$ removal: adsorption property and its improvement with KOH activation. Bioresour. Technol. 169: 622-629.

Jones, C.G., J.H. Lawton, and M. Shachak. 1994. Organisms as ecosystem engineers. Oikos 69:373386. doi:10.2307/3545850

Jones, D.L., G. Edwards-Jones, and D.V. Murphy. 2011. Biochar mediated alterations in herbicide breakdown and leaching in soil. Soil Biol. Biochem. 43:804-813. doi:10.1016/j. soilbio.2010.12.015

Jones, D.L., and R.S. Quilliam. 2014. Metal contaminated biochar and wood ash negatively affect plant growth and soil quality after land application. J. Hazard. Mater. 276:362-370.

Jonker, M.T., and A.A. Koelmans. 2001. Polyoxymethylene solid phase extraction as a partitioning method for hydrophobic organic chemicals in sediment and soot. Environ. Sci. Technol. 35:3742-3748. doi:10.1021/es0100470

Jonker, M.T., S.A. van der Heijden, J.P. Kreitinger, and S.B. Hawthorne. 2007. Predicting PAH bioaccumulation and toxicity in earthworms exposed to manufactured gas plant soils with solid-phase microextraction. Environ. Sci. Technol. 41:7472-7478. doi:10.1021/es070404s

Jo囚ko, I., P. Oleszczuk, J. Pranagal, J. Lehmann, B. Xing, and G. Cornelissen. 2013. Effect of biochars, activated carbon and multiwalled carbon nanotubes on phytotoxicity of sediment contaminated by inorganic and organic pollutants. Ecol. Eng. 60:50-59. doi:10.1016/j. ecoleng.2013.07.064

Jouquet, P., J. Dauber, J. Lagerlöf, P. Lavelle, and M. Lepage. 2006. Soil invertebrates as ecosystem engineers: Intended and accidental effects on soil and feedback loops. Appl. Soil Ecol. 32:153164. doi:10.1016/j.apsoil.2005.07.004

Karami, N., R. Clemente, E. Moreno-Jiménez, N.W. Lepp, and L. Beesley. 2011. Efficiency of green waste compost and biochar soil amendments for reducing lead and copper mobility and uptake to ryegrass. J. Hazard. Mater. 191:41-48. doi:10.1016/j.jhazmat.2011.04.025

Khan, S., C. Chao, M. Waqas, H.P.H. Arp, and Y.-G. Zhu. 2013. Sewage sludge biochar influence upon rice (Oryza sativa $L$ ) yield, metal bioaccumulation and greenhouse gas emissions from acidic paddy soil. Environ. Sci. Technol. 47:8624-8632.

Kılıç, M., Ç. Kırbıyık, Ö. Çepelio®ullar, and A.E. Pütün. 2013. Adsorption of heavy metal ions from aqueous solutions by bio-char, a by-product of pyrolysis. Appl. Surf. Sci. 283:856-862. 
Kim, J.-Y., et al. 2012. Characterization of pyrolytic products obtained from fast pyrolysis of chromated copper arsenate (CCA)-and alkaline copper quaternary compounds (ACQ)-treated wood biomasses. J. Hazard. Mater. 227-228:445-452. doi:10.1016/j.jhazmat.2012.05.052

Kim, P., et al. 2013. Effect of pH on surface characteristics of switchgrass-derived biochars produced by fast pyrolysis. Chemosphere 90:2623-2630. doi:10.1016/j.chemosphere.2012.11.021

Kjellerup, B.V., C. Naff, S.J. Edwards, U. Ghosh, J.E. Baker, and K.R. Sowers. 2014. Effects of activated carbon on reductive dechlorination of $\mathrm{PCBs}$ by organohalide respiring bacteria indigenous to sediments. Water Res. 52:1-10. doi:10.1016/j.watres.2013.12.030

Kołody凶ska, D., R. Wn囚trzak, J.J. Leahy, M.H.B. Hayes, W. Kwapi凶ski, and Z. Hubicki. 2012. Kinetic and adsorptive characterization of biochar in metal ions removal. Chem. Eng. J. 197:295-305. doi:10.1016/j.cej.2012.05.025

Kookana, R.S. 2010. The role of biochar in modifying the environmental fate, bioavailability, and efficacy of pesticides in soils: A review. Soil Res. 48:627-637. doi:10.1071/SR10007

Lattao, C., X. Cao, J. Mao, K. Schmidt-Rohr, and J.J. Pignatello. 2014. Influence of molecular structure and adsorbent properties on sorption of organic compounds to a temperature series of wood chars. Environ. Sci. Technol. 48:4790-4798. doi:10.1021/es405096q

Lehmann, J., M.C. Rillig, J. Thies, C.A. Masiello, W.C. Hockaday, and D. Crowley. 2011. Biochar effects on soil biota-A review. Soil Biol. Biochem. 43:1812-1836. doi:10.1016/j.soilbio.2011.04.022

Lim, W.C., C. Srinivasakannan, and N. Balasubramanian. 2010. Activation of palm shells by phosphoric acid impregnation for high yielding activated carbon. J. Anal. Appl. Pyrolysis 88:181-186. doi:10.1016/j.jaap.2010.04.004

Lua, A.C., and J. Guo. 1998. Preparation and characterization of chars from oil palm waste. Carbon 36:1663-1670. doi:10.1016/S0008-6223(98)00161-4

Lucchini, P., R. Quilliam, T.H. DeLuca, T. Vamerali, and D.L. Jones. 2014a. Increased bioavailability of metals in two contrasting agricultural soils treated with waste wood-derived biochar and ash. Environ. Sci. Pollut. Res. 21:3230-3240. doi:10.1007/s11356-013-2272-y

Lucchini, P., R.S. Quilliam, T.H. DeLuca, T. Vamerali, and D.L. Jones. 2014b. Does biochar application alter heavy metal dynamics in agricultural soil? Agric. Ecosyst. Environ. 184:149157. doi:10.1016/j.agee.2013.11.018

Madrid, F., R. Lopez, and F. Cabrera. 2007. Metal accumulation in soil after application of municipal solid waste compost under intensive farming conditions. Agric. Ecosyst. Environ. 119:249-256. doi:10.1016/j.agee.2006.07.006

Martin, S.M., R.S. Kookana, L. Van Zwieten, and E. Krull. 2012. Marked changes in herbicide sorption-desorption upon ageing of biochars in soil. J. Hazard. Mater. 231-232:70-78. doi:10.1016/j.jhazmat.2012.06.040

Matsuura, H., T. Matsumoto, and F. Tsukihashi. 2009. Behavior of heavy metals during incineration of CCA treated wood waste. J. Iron Steel Res. Int. 16:437-439.

Mello De Capitani, et al. 2007. Wood charcoal and activated carbon dust pneumoconiosis in three workers. Am. J. Ind. Med. 50:191-196. doi:10.1002/ajim.20418

Meynet, P., E. Moliterni, R.J. Davenport, W.T. Sloan, J.V. Camacho, and D. Werner. 2014. Predicting the effects of biochar on volatile petroleum hydrocarbon biodegradation and emanation from soil: A bacterial community finger-print analysis inferred modelling approach. Soil Biol. Biochem. 68:20-30. doi:10.1016/j.soilbio.2013.09.015

Mukherjee, A., and A.R. Zimmerman. 2013. Organic carbon and nutrient release from a range of laboratory-produced biochars and biochar-soil mixtures. Geoderma 193-194:122-130. doi:10.1016/j.geoderma.2012.10.002

Mukherjee, A., A.R. Zimmerman, and W. Harris. 2011. Surface chemistry variations among a series of laboratory-produced biochars. Geoderma 163:247-255. doi:10.1016/j.geoderma.2011.04.021

Nolan, A.L., H. Zhang, and M.J. McLaughlin. 2005. Prediction of zinc, cadmium, lead, and copper availability to wheat in contaminated soils using chemical speciation, diffusive gradients in thin films, extraction, and isotopic dilution techniques. J. Environ. Qual. 34:496-507. doi:10.2134/jeq2005.0496

Novak, J.M., W.J. Busscher, D.L. Laird, M. Ahmedna, D.W. Watts, and M.A. Niandou. 2009. Impact of biochar amendment on fertility of a southeastern coastal plain soil. Soil Sci. 174:105-112. doi:10.1097/SS.0b013e3181981d9a

Omil, B., V. Piñeiro, and A. Merino. 2007. Trace elements in soils and plants in temperate forest plantations subjected to single and multiple applications of mixed wood ash. Sci. Total Environ. 381:157-168. doi:10.1016/j.scitotenv.2007.04.004 
Park, J., G. Choppala, N. Bolan, J. Chung, and T. Chuasavathi. 2011. Biochar reduces the bioavailability and phytotoxicity of heavy metals. Plant Soil 348:439-451. doi:10.1007/ s11104-011-0948-y

Payne, R.B., S.K. Fagervold, H.D. May, and K.R. Sowers. 2013. Remediation of polychlorinated biphenyl impacted sediment by concurrent bioaugmentation with anaerobic halorespiring and aerobic degrading bacteria. Environ. Sci. Technol. 47:3807-3815. doi:10.1021/es304372t

Peralta-Videa, J.R., M.L. Lopez, M. Narayan, G. Saupe, and J. Gardea-Torresdey. 2009. The biochemistry of environmental heavy metal uptake by plants: Implications for the food chain. Int. J. Biochem. Cell Biol. 41:1665-1677. doi:10.1016/j.biocel.2009.03.005

Pérez-de-Mora, A., E. Madejón, P. Burgos, and F. Cabrera. 2006. Trace element availability and plant growth in a mine-spill contaminated soil under assisted natural remediation I. Soils. Sci. Total Environ. 363:28-37. doi:10.1016/j.scitotenv.2005.10.015

Pignatello, J.J., S. Kwon, and Y. Lu. 2006. Effect of natural organic substances on the surface and adsorptive properties of environmental black carbon (char): Attenuation of surface activity by humic and fulvic acids. Environ. Sci. Technol. 40:7757-7763. doi:10.1021/es061307m

Praharaj, T., M. Powell, B. Hart, and S. Tripathy. 2002. Leachability of elements from sub-bituminous coal fly ash from India. Environ. Int. 27:609-615. doi:10.1016/S0160-4120(01)00118-0

Qin, G., D. Gong, and M.-Y. Fan. 2013. Bioremediation of petroleum-contaminated soil by biostimulation amended with biochar. Int. Biodeterior. Biodegrad. 85:150-155. doi:10.1016/j. ibiod.2013.07.004

Quilliam, R.S., H.C. Glanville, S.C. Wade, and D.L. Jones. 2013a. Life in the 'charosphere'-Does biochar in agricultural soil provide a significant habitat for microorganisms? Soil Biol. Biochem. 65:287-293. doi:10.1016/j.soilbio.2013.06.004

Quilliam, R.S., S. Rangecroft, B.A. Emmett, T.H. Deluca, and D.L. Jones. 2013b. Is biochar a source or sink for polycyclic aromatic hydrocarbon (PAH) compounds in agricultural soils? GCB Bioenergy 5:96-103. doi:10.1111/gcbb.12007

Rees, F., M.O. Simonnot, and J.L. Morel. 2014a. Direct and indirect effects of biochar on the mobility of metals and nutrients in contaminated soils: A two-column leaching experiment. Geophys. Res. Abstr. 16:EGU2014-6972.

Rees, F., M.O. Simonnot, and J.L. Morel. 2014b. Short-term effects of biochar on soil heavy metal mobility are controlled by intra-particle diffusion and soil pH increase. Eur. J. Soil Sci. 65:149161. doi:10.1111/ejss.12107

Regmi, P., J.L. Garcia Moscoso, S. Kumar, X. Cao, J. Mao, and G. Schafran. 2012. Removal of copper and cadmium from aqueous solution using switchgrass biochar produced via hydrothermal carbonization process. J. Environ. Manage. 109:61-69. doi:10.1016/j.jenvman.2012.04.047

Reichenberg, F., and P. Mayer. 2006. Two complementary sides of bioavailability: Accessibility and chemical activity of organic contaminants in sediments and soils. Environ. Toxicol. Chem. 25:1239-1245. doi:10.1897/05-458R.1

Reid, B.J., F.L. Pickering, A. Freddo, M.J. Whelan, and F. Coulon. 2013. Influence of biochar on isoproturon partitioning and bioaccessibility in soil. Environ. Pollut. 181:44-50. doi:10.1016/j. envpol.2013.05.042

Reid, B.J., J.D. Stokes, K.C. Jones, and K.T. Semple. 2000. Nonexhaustive cyclodextrin-based extraction technique for the evaluation of PAH bioavailability. Environ. Sci. Technol. 34:31743179. doi:10.1021/es990946c

Rhodes, A.H., A. Carlin, and K.T. Semple. 2008. Impact of black carbon in the extraction and mineralization of phenanthrene in soil. Environ. Sci. Technol. 42:740-745. doi:10.1021/ es071451n

Rhodes, A.H., L.E. McAllister, R. Chen, and K.T. Semple. 2010. Impact of activated charcoal on the mineralisation of ${ }^{14} \mathrm{C}$-phenanthrene in soils. Chemosphere 79:463-469. doi:10.1016/j. chemosphere.2010.01.032

Rittenhouse, J.L., P.J. Rice, K.A. Spokas, and W.C. Koskinen. 2014. Assessing biochar's ability to reduce bioavailability of aminocyclopyrachlor in soils. Environ. Pollut. 189:92-97. doi:10.1016/j. envpol.2014.02.022

Robinson, B.H., G. Bañuelos, H.M. Conesa, M.W.H. Evangelou, and R. Schulin. 2009. The phytomanagement of trace elements in soil. Crit. Rev. Plant Sci. 28:240-266. doi:10.1080/07352680903035424

Rodríguez-Vila, A., E. Covelo, R. Forján and V. Asensio. 2014. Phytoremediating a copper mine soil with Brassica juncea L., compost and biochar. Environ. Sci. Pollut. Res. Int. 21:11,2293-11,304. 
Semple, K.T., K.J. Doick, K.C. Jones, P. Burauel, A. Craven, and H. Harms. 2004. Defining bioavailability and bioaccessibility of contaminated soil and sediment is complicated. Environ. Sci. Technol. 38:228A-231A. doi:10.1021/es040548w

Sizmur, T., B. Palumbo-Roe, and M.E. Hodson. 2011a. Impact of earthworms on trace element solubility in contaminated mine soils amended with green waste compost. Environ. Pollut. 159:1852-1860. doi:10.1016/j.envpol.2011.03.024

Sizmur, T., B. Palumbo-Roe, M.J. Watts, and M.E. Hodson. 2011b. Impact of the earthworm Lumbricus terrestris (L.) on $\mathrm{As}, \mathrm{Cu}, \mathrm{Pb}$ and $\mathrm{Zn}$ mobility and speciation in contaminated soils. Environ. Pollut. 159:742-748. doi:10.1016/j.envpol.2010.11.033

Sizmur, T., E.L. Tilston, J. Charnock, B. Palumbo-Roe, M.J. Watts, and M.E. Hodson. 2011c. Impacts of epigeic, anecic and endogeic earthworms on metal and metalloid mobility and availability. J. Environ. Monit. 13:266-273. doi:10.1039/COEM00519C

Sizmur, T., M.J. Watts, G.D. Brown, B. Palumbo-Roe, and M.E. Hodson. 2011d. Impact of gut passage and mucus secretion by the earthworm Lumbricus terrestris on mobility and speciation of arsenic in contaminated soil. J. Hazard. Mater. 197:169-175. doi:10.1016/j.jhazmat.2011.09.071

Sizmur, T., J. Wingate, T. Hutchings, and M.E. Hodson. 2011e. Lumbricus terrestris L. does not impact on the remediation efficiency of compost and biochar amendments. Pedobiologia 54(Supplement):S211-S216. doi:10.1016/j.pedobi.2011.08.008

Sneath, H.E., T.R. Hutchings, and F.A.A.M. de Leij. 2013. Assessment of biochar and iron filing amendments for the remediation of a metal, arsenic and phenanthrene co-contaminated spoil. Environ. Pollut. 178:361-366. doi:10.1016/j.envpol.2013.03.009

Song, Y., et al. 2012. Bioavailability assessment of hexachlorobenzene in soil as affected by wheat straw biochar. J. Hazard. Mater. 217-218:391-397. doi:10.1016/j.jhazmat.2012.03.055

Sparks, D.L. 2003. Environmental soil chemistry. Academic Press, Boston, MA.

Steiner, C., et al. 2007. Long term effects of manure, charcoal and mineral fertilization on crop production and fertility on a highly weathered Central Amazonian upland soil. Plant Soil 291:275-290. doi:10.1007/s11104-007-9193-9

Sun, H., W.C. Hockaday, C.A. Masiello, and K. Zygourakis. 2012a. Multiple controls on the chemical and physical structure of biochars. Ind. Eng. Chem. Res. 51:3587-3597. doi:10.1021/ie201309r

Sun, J., F. Lian, Z. Liu, L. Zhu, and Z. Song. 2014. Biochars derived from various crop straws: Characterization and Cd (II) removal potential. Ecotoxicol. Environ. Safety 106:226-231.

Sun, K., et al. 2012b. Assessment of herbicide sorption by biochars and organic matter associated with soil and sediment. Environ. Pollut. 163:167-173. doi:10.1016/j.envpol.2011.12.015

Sun, X., and U. Ghosh. 2007. PCB bioavailability control in lumbriculus variegatus through different modes of activated carbon addition to sediments. Environ. Sci. Technol. 41:47744780. doi:10.1021/es062934e

Tao, Y., S. Zhang, Z. Wang, and P. Christie. 2009. Predicting bioavailability of PAHs in fieldcontaminated soils by passive sampling with triolein embedded cellulose acetate membranes. Environ. Pollut. 157:545-551. doi:10.1016/j.envpol.2008.09.030

Tordoff, G., A. Baker, and A. Willis. 2000. Current approaches to the revegetation and reclamation of metalliferous mine wastes. Chemosphere 41:219-228. doi:10.1016/S0045-6535(99)00414-2

Uchimiya, M., S. Chang, and K.T. Klasson. 2011a. Screening biochars for heavy metal retention in soil: Role of oxygen functional groups. J. Hazard. Mater. 190:432-441. doi:10.1016/j. jhazmat.2011.03.063

Uchimiya, M., I.M. Lima, K. Thomas Klasson, S. Chang, L.H. Wartelle, and J.E. Rodgers. 2010. Immobilization of heavy metal ions (Cull, CdII, Nill, and PbII) by broiler litter-derived biochars in water and soil. J. Agric. Food Chem. 58:5538-5544. doi:10.1021/jf9044217

Uchimiya, M., L.H. Wartelle, and V.M. Boddu. 2012. Sorption of triazine and organophosphorus pesticides on soil and biochar. J. Agric. Food Chem. 60:2989-2997.

Uchimiya, M., L.H. Wartelle, K.T. Klasson, C.A. Fortier, and I.M. Lima. 2011b. Influence of pyrolysis temperature on biochar property and function as a heavy metal sorbent in soil. J. Agric. Food Chem. 59:2501-2510. doi:10.1021/jf104206c

Uski, O.J., et al. 2012. Acute systemic and lung inflammation in C57BI/6J mice after intratracheal aspiration of particulate matter from small-scale biomass combustion appliances based on old and modern technologies. Inhal. Toxicol. 24:952-965. doi:10.3109/08958378.2012.742172

Van Wesenbeeck, S., W. Prins, F. Ronsse, and M.J. Antal. 2014. Sewage sludge carbonization for biochar applications. Fate of heavy metals. Energy Fuels 28:5318-5326.

Van Zwieten, L., et al. 2010. A glasshouse study on the interaction of low mineral ash biochar with nitrogen in a sandy soil. Soil Res. 48:569-576. doi:10.1071/SR10003 
Vassilev, S.V., D. Baxter, L.K. Andersen, and C.G. Vassileva. 2013. An overview of the composition and application of biomass ash.: Part 2. Potential utilisation, technological and ecological advantages and challenges. Fuel 105:19-39. doi:10.1016/j.fuel.2012.10.001

Venegas, A., A. Rigol, and M. Vidal. 2015. Viability of organic wastes and biochars as amendments for the remediation of heavy metal-contaminated soils. Chemosphere 119:190-198.

Wang, F., R. Ji, Z. Jiang, and W. Chen. 2014. Species-dependent effects of biochar amendment on bioaccumulation of atrazine in earthworms. Environ. Pollut. 186:241-247. doi:10.1016/j. envpol.2013.12.012

Wang, X., and B. Xing. 2007. Sorption of organic contaminants by biopolymer-derived chars. Environ. Sci. Technol. 41:8342-8348. doi:10.1021/es071290n

Wang, Y., et al. 2013. Reducing the bioavailability of PCBs in soil to plant by biochars assessed with triolein-embedded cellulose acetate membrane technique. Environ. Pollut. 174:250-256. doi:10.1016/j.envpol.2012.12.004

Welham, S.J., S.A. Gezan, S.J. Clark and A. Mead. 2014. Statistical methods in biology: Design and analysis of experiments and regression. CRC Press, Boca Raton, FL.

Weng, L., E.J.M. Temminghoff, S. Lofts, E. Tipping, and W.H. Van Riemsdijk. 2002. Complexation with dissolved organic matter and solubility control of heavy metals in a sandy soil. Environ. Sci. Technol. 36:4804-4810. doi:10.1021/es0200084

Wnetrzak, R., et al. 2014. Influence of pig manure biochar mineral content on $\mathrm{Cr}$ (III) sorption capacity. J. Chem. Technol. Biotechnol. 89:569-578.

Xia, X., Y. Li, Z. Zhou, and C. Feng. 2010. Bioavailability of adsorbed phenanthrene by black carbon and multi-walled carbon nanotubes to Agrobacterium. Chemosphere 78:1329-1336. doi:10.1016/j.chemosphere.2010.01.007

Xin, J., X. Liu, W. Liu, and X. Zheng. 2014. Effects of biochar-BDE-47 interactions on BDE-47 bioaccessibility and biodegradation by Pseudomonas putida TZ-1. Ecotoxicol. Environ. Saf. 106:27-32. doi:10.1016/j.ecoenv.2014.04.036

Xu, T., L. Lou, L. Luo, R. Cao, D. Duan, and Y. Chen. 2012. Effect of bamboo biochar on pentachlorophenol leachability and bioavailability in agricultural soil. Sci. Total Environ. 414:727-731. doi:10.1016/j.scitotenv.2011.11.005

Xu, X., X. Cao, and L. Zhao. 2013. Comparison of rice husk- and dairy manure-derived biochars for simultaneously removing heavy metals from aqueous solutions: Role of mineral components in biochars. Chemosphere 92:955-961.

Xue, Y., et al. 2012. Hydrogen peroxide modification enhances the ability of biochar (hydrochar) produced from hydrothermal carbonization of peanut hull to remove aqueous heavy metals: Batch and column tests. Chem. Eng. J. 200-202:673-680. doi:10.1016/j.cej.2012.06.116

Yamato, M., Y. Okimori, I.F. Wibowo, S. Anshori, and M. Ogawa. 2006. Effects of the application of charred bark of Acacia mangium on the yield of maize, cowpea and peanut, and soil chemical properties in South Sumatra, Indonesia. Soil Sci. Plant Nutr. 52:489-495. doi:10.1111/j.1747-0765.2006.00065.x

Yoshida, T., and M.J. Antal Jr. 2009. Sewage sludge carbonization for terra preta applications. Energy Fuels 23:5454-5459. doi:10.1021/ef900610k

Zhang, H., F.-J. Zhao, B. Sun, W. Davison, and S.P. Mcgrath. 2001. A new method to measure effective soil solution concentration predicts copper availability to plants. Environ. Sci. Technol. 35:2602-2607. doi:10.1021/es000268q

Zhang, W., S. Mao, H. Chen, L. Huang, and R. Qiu. 2013a. Pb(II) and $\mathrm{Cr}(\mathrm{VI})$ sorption by biochars pyrolyzed from the municipal wastewater sludge under different heating conditions. Bioresour. Technol. 147:545-552. doi:10.1016/j.biortech.2013.08.082

Zhang, Z., Z. Solaiman, K. Meney, D. Murphy, and Z. Rengel. 2013b. Biochars immobilize soil cadmium, but do not improve growth of emergent wetland species Juncus subsecundus in cadmium-contaminated soil. J. Soils Sediments 13:140-151. doi:10.1007/s11368-012-0571-4

Zhou, Y., B. Gao, A.R. Zimmerman, J. Fang, Y. Sun, and X. Cao. 2013. Sorption of heavy metals on chitosan-modified biochars and its biological effects. Chem. Eng. J. 231:512-518. doi:10.1016/j. cej.2013.07.036

Zimmerman, A.R. 2010. Abiotic and microbial oxidation of laboratory-produced black carbon (biochar). Environ. Sci. Technol. 44:1295-1301. doi:10.1021/es903140c

Zimmerman, J.R., D. Werner, U. Ghosh, R.N. Millward, T.S. Bridges, and R.G. Luthy. 2005. Effects of dose and particle size on activated carbon treatment to sequester polychlorinated biphenyls and polycyclic aromatic hydrocarbons in marine sediments. Environ. Toxicol. Chem. 24:15941601. doi:10.1897/04-368R.1 